Article

\title{
Synthesis of Magnetic $\mathrm{Fe}_{3} \mathrm{O}_{4} / \mathrm{ZnWO}_{4}$ and $\mathrm{Fe}_{3} \mathrm{O}_{4} / \mathrm{ZnWO} 4 / \mathrm{CeVO}_{4}$ Nanoparticles: The Photocatalytic Effects on Organic Pollutants upon Irradiation with UV-Vis Light
}

Mohammad Amin Marsooli ${ }^{1,2}$, Mehdi Rahimi Nasrabadi ${ }^{1,2, *}$, Mahdi Fasihi-Ramandi ${ }^{1}$, Kourosh Adib ${ }^{3}$, Saeid Pourmasoud ${ }^{4}$, Farhad Ahmadi ${ }^{5,6}$, Mohammad Eghbali ${ }^{4}$, Ali Sobhani Nasab ${ }^{7,8, *(\mathbb{D})}$, Monika Tomczykowa ${ }^{9}$ (D) and Marta E. Plonska-Brzezinska $9, *$ (D)

1 Molecular Biology Research Center, Systems Biology and Poisoning Institute, Baqiyatallah University of Medical Sciences, Sheikh Bahaei Street, Tehran 1951683759, Iran; mohammadamin.marsuli@gmail.com (M.A.M.); fasihi.m@gmail.com (M.F.-R.)

2 Faculty of Pharmacy, Baqiyatallah University of Medical Sciences, Sheikh Bahaei Street, Tehran 1951683759, Iran

3 Department of Chemistry, Imam Hossein University, Babaei Highway, Tehran 1955735345, Iran; k_anbaz@yahoo.com

4 Department of Physics, University of Kashan, Ravand Street, Kashan 8731753153, Iran; SA_PO2007@yahoo.com (S.P.); SA_POURMASOUD2007@yahoo.com (M.E.)

5 Physiology Research Center, Iran University of Medical Sciences, Hemmat Highway, Tehran 1449614535, Iran; Farhadahmadi55@gmail.com

6 Department of Medicinal Chemistry, School of Pharmacy-International Campus, Iran University of Medical Sciences, Hemmat Highway, Tehran 1451555763, Iran

7 Social Determinants of Health (SDH) Research Center, Kashan University of Medical Sciences, Kashan 8115187159, Iran

8 Core Research Lab, Kashan University of Medical Sciences, Ravand Street, Kashan 8115187159, Iran

9 Department of Organic Chemistry, Faculty of Pharmacy with the Division of Laboratory Medicine, Medical University of Bialystok, Mickiewicza 2A, 15-222 Bialystok, Poland; monika.tomczyk@umb.edu.pl

* Correspondence: rahiminasrabadi@gmail.com (M.R.N.); ali.sobhaninasab@gmail.com (A.S.N.); marta.plonska-brzezinska@umb.edu.pl (M.E.P.-B.); Tel.: +98-2182-483409 (M.R.N.)

Received: 12 March 2020; Accepted: 22 April 2020; Published: 1 May 2020

check for updates

\begin{abstract}
Magnetic $\mathrm{Fe}_{3} \mathrm{O}_{4} / \mathrm{ZnWO}_{4}$ and $\mathrm{Fe}_{3} \mathrm{O}_{4} / \mathrm{ZnWO}_{4} / \mathrm{CeVO}_{4}$ nanoparticles with different molar ratios of $\mathrm{CeVO}_{4}$ to other inorganic components were synthesized through co-precipitation with a sonochemical-assisted method. X-ray diffraction, energy dispersive X-ray spectroscopy, Fourier transform infrared spectroscopy, ultraviolet-visible diffuse reflectance spectroscopy, vibrating sample magnetometry, and scanning electron microscopy (SEM) methods were used for the physico-chemical characterization of the obtained nanoparticles. As shown in the SEM images, the average sizes of the $\mathrm{Fe}_{3} \mathrm{O}_{4} / \mathrm{ZnWO}_{4}$ and $\mathrm{Fe}_{3} \mathrm{O}_{4} / \mathrm{ZnWO}_{4} / \mathrm{CeVO}_{4}$ nanoparticles that formed aggregates were approximately 50-70 nm and 80-100 nm, respectively. The photocatalytic performance of these nanoparticles was examined by measuring methylene blue degradation under visible light (assisted by $\mathrm{H}_{2} \mathrm{O}_{2}$ ). The sample with a mass ratio of 1:2:1 $\left(\mathrm{Fe}_{3} \mathrm{O}_{4} / \mathrm{ZnWO}_{4} / \mathrm{CeVO}_{4}, \mathrm{~S}_{4}\right)$ exhibited optimal photocatalytic performance, and thus this sample was subsequently used for the photodegradation of different organic pollutants upon irradiation with ultraviolet (UV) and visible light. Approximately 90\% and $70 \%$ degradation of methyl violet and methylene blue, respectively, was observed after visible light irradiation. Additionally, the mechanism of the photocatalytic reaction was investigated by measuring $\mathrm{OH}$ release under UV light in a system with terephthalic acid and by measuring the release of $\mathrm{O}_{2}{ }^{-}, \mathrm{OH}$, and hole scavengers.
\end{abstract}


Keywords: magnetic nanoparticles; $\mathrm{Fe}_{3} \mathrm{O}_{4} ; \mathrm{CdWO}_{4} ; \mathrm{CeVO}_{4}$; sonochemical procedure; photocatalysis

\section{Introduction}

The development of human civilization across the earth in the form of population growth and increasing industrialization has resulted in a shortage of healthy wastewater. Wastewater may contain many pathogenic microorganisms and pharmaceutical and chemical residues [1-4]. A large variety of organic compounds are capable of being completely degraded and mineralized into $\mathrm{CO}_{2}$ and harmless inorganic anions. The chemical and pharmaceutical pollutants may include, but are not limited to salts, metalloids, metals, organic compounds, residual drugs, endocrine-disrupting compounds [5-7], and other compounds. Therefore, different methods have been proposed to treat water resources and restore good and healthy properties to water. Different chemical and biological methods have been used to purify industrial, agricultural, and pharmaceutical wastewater and increase the number of existing resources available [8-10].

Photocatalytic processes have become an attractive method for researchers to use to degrade pollutants [11-15]. "Photocatalysis" is a catalytic process driven by light in nature and uses materials called "photocatalysts". Photocatalysis was first reported at the beginning of the nineteenth century, but a boom took place in the field of heterogeneous photocatalysis after an article reported photo-assisted catalysis of water upon irradiation of $\mathrm{TiO}_{2}$ [16]. Semiconductors are frequently used for this process, due to their optical properties, electronic structure, and intrinsic nature [17-21]. Many physical and chemical parameters affect the efficiency of photocatalytic processes, including (i) their chemical composition, such as the elemental composition and chemical state/structure; (ii) physical properties, such as the physical and crystal structures, optical absorption, charge dynamics, defects, and thermal stability; and (iii) band structure (band gap, band edges and Fermi level) [22]. An appropriate band gap is one of the main principles of a photocatalyst [23]. A suitable band gap is important because of the ability to capture light and its effect on redox reactions that are performed by photocatalytic systems designed by incorporating a matrix into the semiconductor or by adding a co-catalyst [24-27].

Photocatalysis, in which a photoinduced chemical reaction occurs on the surface of semiconductor materials (photocatalyst) upon exposure to photons, is a heterogeneous process [14,28]. Photocatalysts are typically composed of metal oxides, oxysulfides, metal sulfides, oxynitrides, their composites [23,29-35], and other materials. The chemical structure and the well-developed surface (morphology) of the materials exert significant effects on the photocatalytic process. The ability to tune the functional and morphological properties of nanocrystals is one of the most important issue in photocatalysis [15], mainly because the size, shape, and porous characteristics of synthesized nanomaterials affect the photocatalytic properties of these materials [34,36-39].

Magnetizing photocatalytic materials is a procedure to easily split a photocatalyst after use. One of the challenges facing the use of photocatalysts is the leakage of metal ions from the catalyst. The use of magnetic nanoparticles reduces the likelihood of metal leakage because the particles might have accumulated an external magnetic field. The most effective magnetic particles are those containing iron oxide core because of their low cost, easy separation, and excellent reusability [40-45]. $\mathrm{Fe}_{3} \mathrm{O}_{4}$ has unique electronic and magnetic characteristics that are the result of complicated electron-electron and electron-phonon interactions [42]. The introduction of other metals into these materials containing iron oxides creates multiferroic systems, which can be developed by exploiting the epitaxial strain, oxygen vacancy, charge, or composition gradients [42]. To conclude, multiferroic heterostructures may have enhanced heterogeneous catalytic activity and selectivity compared with monometallic materials $[40,41,44]$ Among the substantial number of multiferroic heterostructures, one of the main groups is metal tungstates, with the formula of $\mathrm{MWO}_{4}(\mathrm{M}=\mathrm{Co}, \mathrm{Cu}, \mathrm{Zn}, \mathrm{Pb}$, and $\mathrm{Mn})$, and transition metal-based orthovanadates $\left(\mathrm{MVO}_{4}\right)$ [42,46-48]. Metal tungstates possess interesting structural and photoluminescence properties, mainly including ferroelasticity, ionic conductivity, 
and photoluminescence $[47,49]$. Due to their very interesting physico-chemical and nanostructural properties, they have attracted the interest of researchers in many areas. In particular, $\mathrm{ZnWO}_{4}$ has been used in various applications, such as sensors, scintillators, laser hosts, and phase-change optical recording devices [50,51]. In some situations, $\mathrm{ZnWO}_{4}$ is used to photodegrade organic pollutants [37]. Additionally, $\mathrm{MVO}_{4}$ materials are a cohesive class of materials with potential applications in various fields, such as optoelectronics, spintronics, catalysis, solar cells, gas sensors, photoluminescence, and photocatalysis [35,52-54]. Although these two groups of inorganic oxides possess very good photocatalytic properties and degrade organic pollutants, a major problem after their use is their removal from wastewater after the redox reaction. The solution to this problem is to use a photocatalyst with magnetic properties. By preparing nanoparticles or composites with simultaneous photocatalytic and magnetic properties, the used photocatalysts can be extracted for recycling with an external magnetic field [55].

Here, the facile synthesis of magnetic $\mathrm{Fe}_{3} \mathrm{O}_{4} / \mathrm{ZnWO}_{4} / \mathrm{CeVO}_{4}$ nanoparticles at different molar ratios of $\mathrm{CeVO}_{4}$ to $\mathrm{Fe}_{3} \mathrm{O}_{4} / \mathrm{ZnWO}_{4}$ is reported. The molar ratios of subsequent layers were as follows: 1:2:0.5 (designated as $S_{2}$ ), 1:2:0.75 (designated as $S_{3}$ ), 1:2:1 (designated as $S_{4}$ ), and 1:2:1.5 (designated as $S_{5}$ ). The photocatalytic activities of these samples upon irradiation with visible light were compared with $\mathrm{Fe}_{3} \mathrm{O}_{4} / \mathrm{ZnWO}_{4}$ (designated as $\mathrm{S}_{1}$ ) as a reference. The structural, morphological, optical, and magnetic properties of the photocatalysts were determined for the nanoparticles with the highest photocatalytic activity $-S_{4}(1: 2: 1)$. Three dye pollutants, methylene blue (MB), methyl orange (MO), and methyl violet (MV), were employed to measure the photocatalytic activity of the samples after irradiation with visible light (assisted by $\mathrm{H}_{2} \mathrm{O}_{2}, \mathrm{MB}$ was used in an optimization step as a probe). The efficiency of the synthesized samples illuminated with ultraviolet light was tested using MB, fenitrothion (FNT), MO, and rhodamine-B (RhB). The conversion of terephthalic acid (TA) to 2-hydroxy-terephthalic acid in the presence of hydroxyl radicals and with the assistance of $\mathrm{O}_{2}{ }^{-}, \mathrm{OH}$ and hole scavengers was analysed to investigate the mechanism of the photocatalytic reaction.

\section{Results}

\subsection{Physico-Chemical Characterization of $\mathrm{Fe}_{3} \mathrm{O}_{4} / \mathrm{ZnWO}_{4}$ and $\mathrm{Fe}_{3} \mathrm{O}_{4} / \mathrm{ZnWO} / \mathrm{CeVO} \mathrm{Nanoparticles}_{4}$}

X-ray diffraction (XRD) was performed to identify the phase composition and to determine the metal crystallite size and size distribution of the synthesized inorganic nanoparticles $\left(\mathrm{Fe}_{3} \mathrm{O}_{4}\right.$, $\mathrm{Fe}_{3} \mathrm{O}_{4} / \mathrm{ZnWO}_{4}$, and $\left.\mathrm{Fe}_{3} \mathrm{O}_{4} / \mathrm{ZnWO}_{4} / \mathrm{CeVO}_{4}\left(\mathrm{~S}_{4}\right)\right)$. The results of the XRD analyses are shown in Figure 1. Figure 1 a shows the diffraction pattern for $\mathrm{Fe}_{3} \mathrm{O}_{4}$, with the main diffraction peaks observed at $2 \theta$ of $35.6^{\circ}$ (line (311)) and of $63.1^{\circ}$ (line (220)), which correspond to the cubic phases of $\mathrm{Fe}_{3} \mathrm{O}_{4}(72-2303$ JCPDS) [56]. The average crystallite size $\left(D_{c}\right)$ was calculated using the well-known Scherrer formula:

$$
D_{C}=\frac{K \lambda}{\beta \cos \theta}
$$

where $\lambda$ is the X-ray wavelength (nm), $\beta$ is the breadth of the observed diffraction line at half its intensity maximum $[57,58]$, and $\mathrm{K}$ is a constant (0.9) related to the crystallite shape for any $2 \theta$ peak in the pattern $[59,60]$. The average $D_{c}$ value was calculated and was ca. $15 \mathrm{~nm}$. $\mathrm{Fe}_{3} \mathrm{O}_{4} / \mathrm{ZnWO}_{4}$ (Figure $1 \mathrm{~b}$ ) was composed of two pure phases of $\mathrm{Fe}_{3} \mathrm{O}_{4}$ (JCPDS 72-2303) and $\mathrm{ZnWO}_{4}$ (JCPDS 15-0774), with diffraction peaks at the positions of $35.6^{\circ}, 63.1^{\circ}, 30.47^{\circ}, 53.63^{\circ}$, and $64.78^{\circ}$ that corresponded to the lines (311), (220), (111), (202), and (311), respectively. The $D_{c}$ value was estimated as $36.3 \mathrm{~nm}$. The $S_{4}$ profile revealed the presence of a mixture of various phases (Figure 1c). 

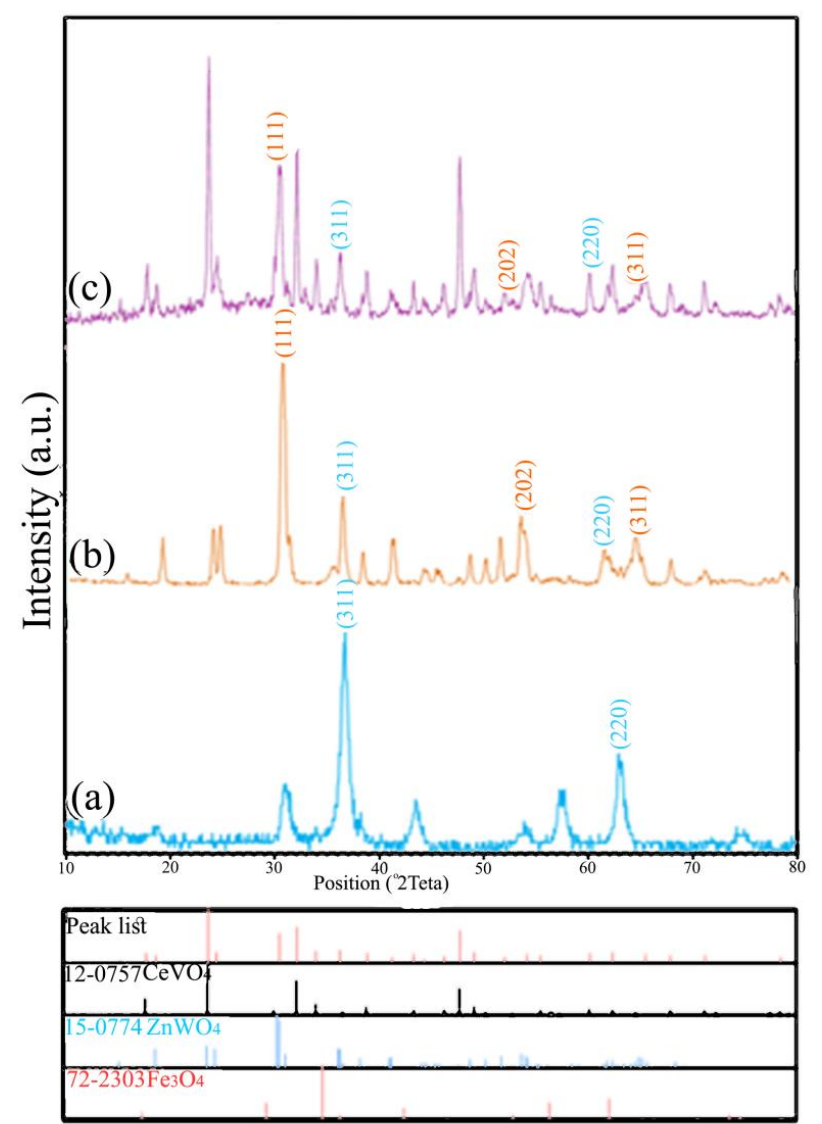

Figure 1. XRD patterns of (a) $\mathrm{Fe}_{3} \mathrm{O}_{4}$, (b) $\mathrm{Fe}_{3} \mathrm{O}_{4} / \mathrm{ZnWO}_{4}\left(\mathrm{~S}_{1}\right)$, and (c) $\mathrm{Fe}_{3} \mathrm{O}_{4} / \mathrm{ZnWO} 4 / \mathrm{CeVO}_{4}\left(\mathrm{~S}_{4}\right)$.

The $\mathrm{Fe}_{3} \mathrm{O}_{4} / \mathrm{ZnWO}_{4} / \mathrm{CeVO}_{4}$ nanoparticles presented a combination of three pure phases of $\mathrm{Fe}_{3} \mathrm{O}_{4}$ (JCPDS 72-2303) [61], $\mathrm{ZnWO}_{4}$ (JCPDS 15-0774) [62], and $\mathrm{CeVO}_{4}$ (JCPDS 12-0757) [63]. The diffraction peaks were observed at $2 \theta$ of $24.03^{\circ}$ (line (200)), $32.04^{\circ}$ (line (112)), and $47.86^{\circ}$ (line (312)), consistent with a pure phase tetragonal $\mathrm{CeVO}_{4}$ nanostructure [64]. The $D_{\mathcal{c}}$ value for the nanohybrid system increased to $58 \mathrm{~nm}$ (Figure 1c). All calculated parameters are summarized in Table 1. In summary, the profiles of all inorganic nanoparticles confirmed the presence of $\mathrm{Fe}_{3} \mathrm{O}_{4}, \mathrm{ZnWO}_{4}$, and $\mathrm{CeVO}_{4}$ components in the obtained materials.

Table 1. Main reflections observed in the XRD patterns of inorganic nanoparticles.

\begin{tabular}{|c|c|c|c|c|c|c|c|}
\hline Sample & $\begin{array}{l}2 \text { Theta } \\
\text { (Degrees) }\end{array}$ & hkl & $\begin{array}{l}\text { Crystallite } \\
\text { Sizes } \\
\text { Dhkl (nm) }\end{array}$ & $\begin{array}{c}\text { Average } \\
\text { Crystallite } \\
\text { Size (nm) }\end{array}$ & A (̊) & B (̊) & $C(\AA)$ \\
\hline $\mathrm{Fe}_{3} \mathrm{O}_{4}$ & $\begin{array}{l}35.6 \\
63.1\end{array}$ & $\begin{array}{l}(311) \\
(220)\end{array}$ & $\begin{array}{l}15.8 \\
14.3\end{array}$ & 0.15 & 8.3740 & 8.3740 & 8.3740 \\
\hline $\mathrm{Fe}_{3} \mathrm{O}_{4} / \mathrm{ZnWO} 4$ & $\begin{array}{c}35.6 \\
63.1 \\
30.47 \\
53.63 \\
64.78\end{array}$ & $\begin{array}{l}(311) \\
(220) \\
(111) \\
(202) \\
(311)\end{array}$ & $\begin{array}{l}16.33 \\
15.40 \\
12.60 \\
13.62 \\
14.79\end{array}$ & 36.3 & 4.6910 & 5.7200 & 4.9250 \\
\hline $\mathrm{Fe}_{3} \mathrm{O}_{4} / \mathrm{ZnWO}_{4} / \mathrm{CeVO}_{4}$ & $\begin{array}{c}35.6 \\
63.1 \\
30.47 \\
53.63 \\
64.78 \\
24.03 \\
32.40 \\
47.86\end{array}$ & $\begin{array}{l}(311) \\
(220) \\
(111) \\
(202) \\
(311) \\
(200) \\
(112) \\
(322)\end{array}$ & $\begin{array}{l}16.68 \\
16.01 \\
14.02 \\
15.32 \\
16.14 \\
14.63 \\
12.67 \\
11.96\end{array}$ & 58.7 & 7.3990 & 7.3990 & 6.4960 \\
\hline
\end{tabular}


An energy dispersive X-ray (EDX) analysis of the $\mathrm{Fe}_{3} \mathrm{O}_{4} / \mathrm{ZnWO}_{4} / \mathrm{CeVO}_{4}\left(\mathrm{~S}_{4}\right)$ material was performed to confirm the purity of the synthesized nanoparticles and the presence of individual elements (Figure 2f). Figure $2 \mathrm{f}$ displays the presence of subsequent elements, $\mathrm{W}, \mathrm{Fe}, \mathrm{Zn}, \mathrm{O}, \mathrm{Ce}$, and $\mathrm{V}$, in $\mathrm{Fe}_{3} \mathrm{O}_{4} / \mathrm{ZnWO}_{4} / \mathrm{CeVO}_{4}$. The atomic ratio of these elements in this nanoparticle were as follows: $12.81(\mathrm{Fe}), 54.35(\mathrm{O}), 5.63(\mathrm{Zn}), 7.81(\mathrm{~W}), 6.19(\mathrm{Ce})$, and 13.21\% (V).

The morphology of the obtained materials was examined using scanning electron microscopy (SEM), and the results are presented in Figure 2. The SEM images indicate the difference between the nanoparticles with different molar ratios of inorganic components $\left(\mathrm{Fe}_{3} \mathrm{O}_{4}\right.$ and $\mathrm{ZnWO}_{4}$ and $\left.\mathrm{CeVO}_{4}\right)$ and they do not exhibit single and separated $\mathrm{Fe}_{3} \mathrm{O}_{4} / \mathrm{ZnWO}_{4} / \mathrm{CeVO}_{4}$ nanoparticles. The inorganic nanoparticles were formed by nanoclusters, with a different distribution following a concentration-dependent process (Figure $2 \mathrm{~b}-\mathrm{e}$ ). The smallest $\mathrm{Fe}_{3} \mathrm{O}_{4} / \mathrm{ZnWO}_{4} / \mathrm{CeVO}_{4}$ aggregates formed the sample with the molar ratios of 1:2:1 $\left(\mathrm{S}_{4}\right)$. The agglomerates of $\mathrm{Fe}_{3} \mathrm{O}_{4} / \mathrm{ZnWO}_{4} / \mathrm{CeVO}_{4}$ nanoparticles with different dimensions formed a spongy-like structure with an increasing diameter after the deposition of subsequent inorganic layers. An average size of $50-70 \mathrm{~nm}$ for $S_{1}$ and $80-100 \mathrm{~nm}$ for $\mathrm{S}_{4}$ was determined based on these results (Figure 2a,d, respectively). Additionally, the results confirmed that the size of the nanoparticle aggregates obtained from the SEM images was larger than the size identified using XRD. The SEM images show the diameters of various crystallites created after the evaporation of the solvent in which the nanoparticles were dispersed.

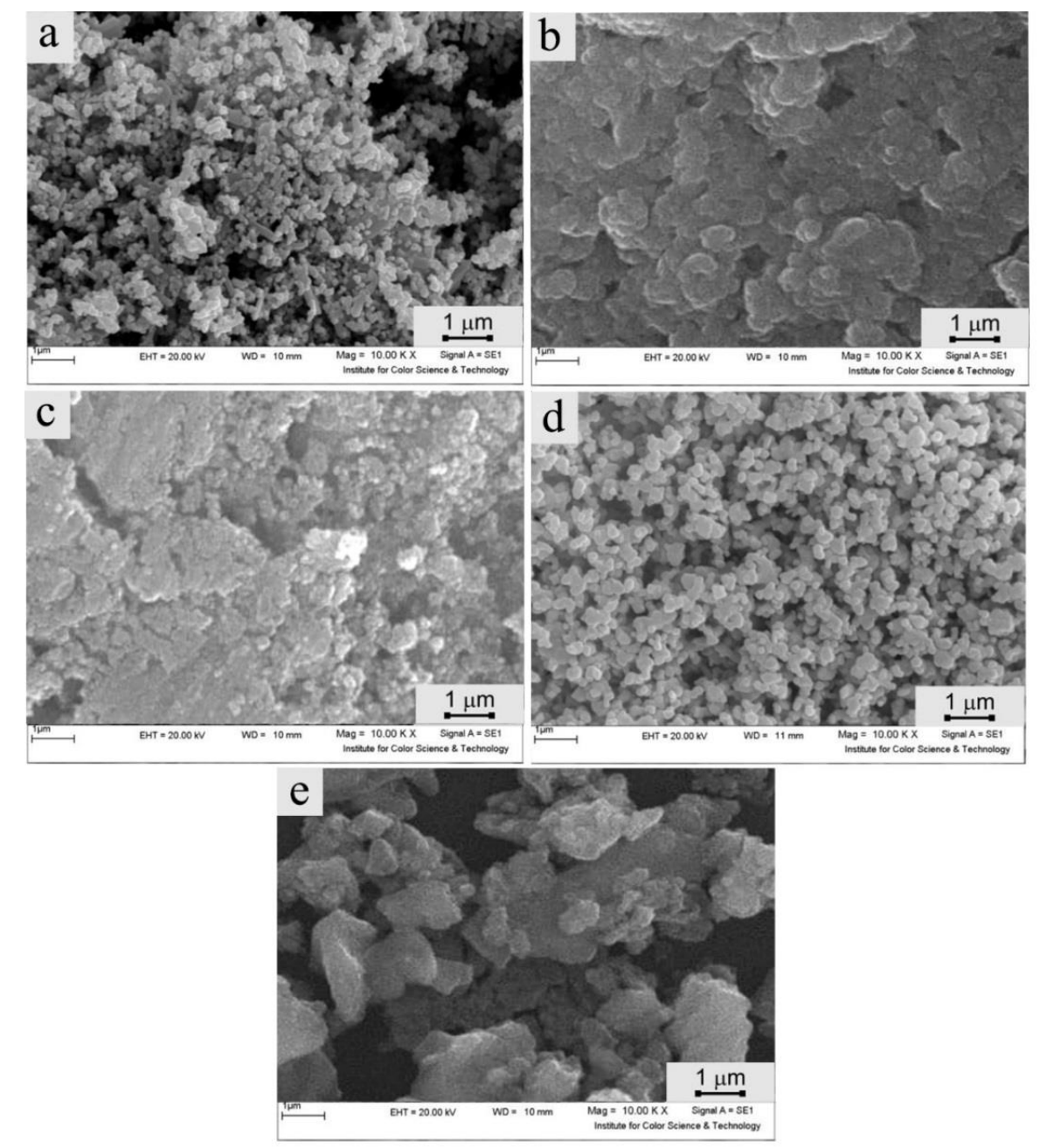

Figure 2. Cont. 


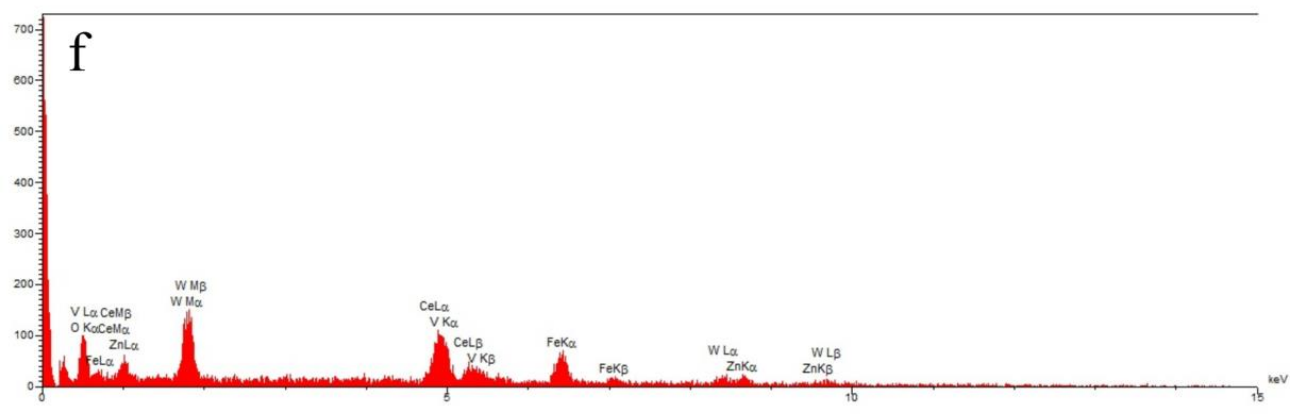

Figure 2. SEM images of (a) $\mathrm{Fe}_{3} \mathrm{O}_{4} / \mathrm{ZnWO}_{4}\left(\mathrm{~S}_{1}\right)$, and $\mathrm{Fe}_{3} \mathrm{O}_{4} / \mathrm{ZnWO}_{4} / \mathrm{CeVO}_{4}$ with the molar ratios of (b) 1:2:0.5 $\left(\mathrm{S}_{2}\right),(\mathbf{c})$ 1:2:0.75 $\left(\mathrm{S}_{3}\right),(\mathbf{d})$ 1:2:1 $\left(\mathrm{S}_{4}\right)$, and (e) 1:2:1.5 ( $\left.\mathrm{S}_{5}\right)$. (f) EDX spectrum of the $\mathrm{Fe}_{3} \mathrm{O}_{4} / \mathrm{ZnWO}_{4} / \mathrm{CeVO}_{4}$ $\left(\mathrm{S}_{4}\right)$ sample.

Figure 3 shows the magnetic hysteresis loops of (a) $\mathrm{Fe}_{3} \mathrm{O}_{4}$ and (b) $\mathrm{Fe}_{3} \mathrm{O}_{4} / \mathrm{ZnWO}_{4} / \mathrm{CeVO}_{4}\left(\mathrm{~S}_{4}\right)$ at $300 \mathrm{~K}$. As shown in this figure, $\mathrm{Fe}_{3} \mathrm{O}_{4}$ and $\mathrm{Fe}_{3} \mathrm{O}_{4} / \mathrm{ZnWO}_{4} / \mathrm{CeVO}_{4}$ displayed magnetization saturation $\left(M_{s}\right)$ values of 50.9 and $1.5 \mathrm{emu} \mathrm{g}^{-1}$, respectively. The saturation magnetization of $\mathrm{Fe}_{3} \mathrm{O}_{4} / \mathrm{ZnWO}_{4} / \mathrm{CeVO}_{4}$ nanoparticles was lower than that of unmodified $\mathrm{Fe}_{3} \mathrm{O}_{4}$, which is related to the additional inorganic layers $\left(\mathrm{ZnWO}_{4} / \mathrm{CeVO}_{4}\right)$. However, the magnetization of $\mathrm{Fe}_{3} \mathrm{O}_{4} / \mathrm{ZnWO}_{4} / \mathrm{CeVO}_{4}$ nanoparticles was sufficient for the magnetic separation of photocatalysts from the treated solution using an external magnetic field.

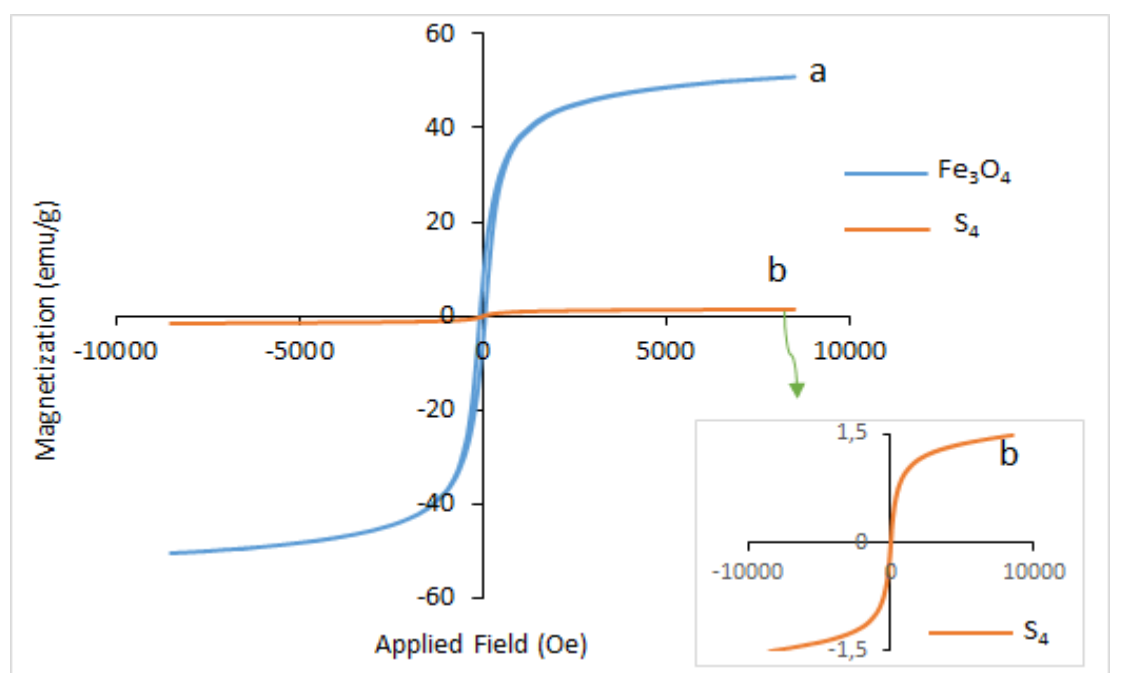

Figure 3. Magnetic hysteresis loops of (a) $\mathrm{Fe}_{3} \mathrm{O}_{4}$ and (b) $\mathrm{Fe}_{3} \mathrm{O}_{4} / \mathrm{ZnWO}_{4} / \mathrm{CeVO}_{4}$.

The light absorption properties of materials play a significant role in their photocatalytic activities [63]. The relationship between the energy and absorption edge was calculated using Tauc's Equation [65]:

$$
\alpha h v=A\left(h v-E_{g}\right)^{\eta}
$$

where $h$ is Planck's constant, $v$ is the frequency of light, $\alpha$ is the absorption coefficient, $E_{g}$ is the optical band gap energy (OBGE), A is a constant, and $\eta$ is 0.5 or 2 for direct or indirect transitions, respectively. The value of $\eta=2$ was considered in this experiment [66]. Based on the data shown in Tauc's plot of the $S_{1}$ and $S_{4}$ samples (Figure 4), the OBGE values were ca. 3.1 and $2.6 \mathrm{eV}$, respectively. Generally, the OBGE values may be affected by the surface and interface effect, change in crystal structure, and lattice strain in the structure [67]. However, the $S_{1}$ sample had a higher OBGE value; a combination of $\mathrm{Fe}_{3} \mathrm{O}_{4}$ conductivity with visible light active semiconductivity is frequently required for photocatalytic purposes. Herein, we report $\mathrm{Fe}_{3} \mathrm{O}_{4} / \mathrm{ZnWO}_{4} / \mathrm{CeVO}_{4}$ hierarchical core-shell structures 
that enhanced the electron-hole separation $\left(\mathrm{Fe}_{3} \mathrm{O}_{4}\right)$ and light harvesting $\left(\mathrm{ZnWO}_{4} / \mathrm{CeVO}_{4}\right)$ due to their multifunctionality and synergetic effect on every component [68].

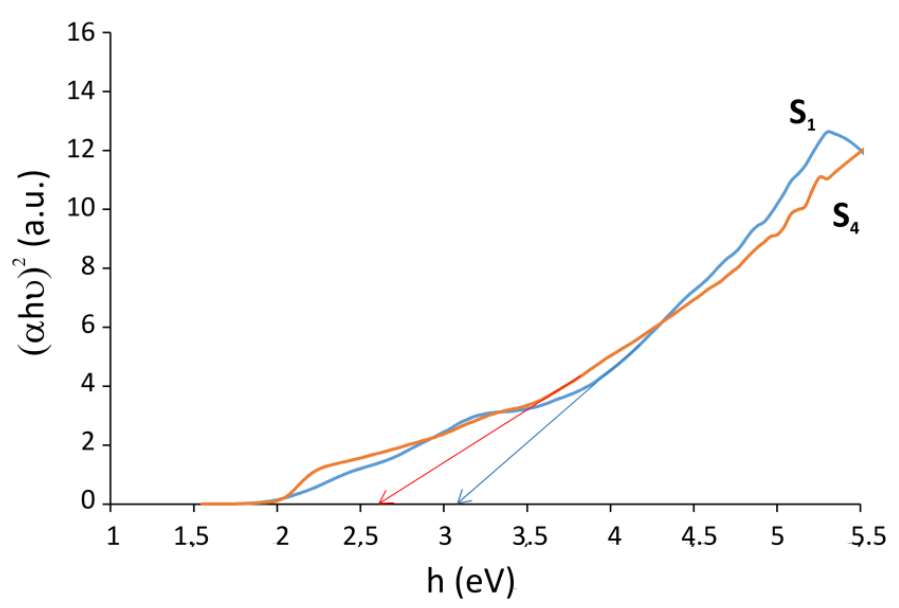

Figure 4. Tauc's plot of the $S_{1}$ and $S_{4}$ samples.

Fourier transform infrared spectroscopy (FTIR) was performed to assess the chemical structure of $\mathrm{Fe}_{3} \mathrm{O}_{4}, \mathrm{Fe}_{3} \mathrm{O}_{4} / \mathrm{ZnWO}_{4}\left(\mathrm{~S}_{1}\right), \mathrm{Fe}_{3} \mathrm{O}_{4} / \mathrm{ZnWO}_{4} / \mathrm{CeVO}_{4}\left(\mathrm{~S}_{4}\right)$ (before and after calcination), and $\mathrm{S}_{4}$ after the photocatalytic removal of $\mathrm{MB}$ at a concentration of $25 \mathrm{mg} \mathrm{L}^{-1}$. The measurements were conducted in the range of 500-3500 $\mathrm{cm}^{-1}$, and the outcomes are presented in Figure 5. The bands at 3390-3410 and $1620-1638 \mathrm{~cm}^{-1}$ were assigned to the $\mathrm{O}-\mathrm{H}$ stretching vibration due to the presence of surface hydroxyl groups and $\mathrm{H}_{2} \mathrm{O}$. In Figure $5 \mathrm{a}$, the absorption peak observed at $587 \mathrm{~cm}^{-1}$ is attributed to the $\mathrm{Fe}-\mathrm{O}$ vibration from the magnetite phase [69]. The absorption band at $620 \mathrm{~cm}^{-1}$ originated from symmetrical vibrations of the bridging oxygen atoms of the $\mathrm{Zn}-\mathrm{O}-\mathrm{W}$ groups (Figure 5b) [70]. The absorption bands at 820 and $888 \mathrm{~cm}^{-1}$ are attributed to the vibration of the $\mathrm{WO}_{2}$ units in the $\mathrm{W}_{2} \mathrm{O}_{8}$ system. Figure $5 \mathrm{c}, \mathrm{d}$ show the FTIR spectra of the $\mathrm{S}_{4}$ sample before and after calcination, respectively. The peaks at 839 and $822 \mathrm{~cm}^{-1}$ represent the V-O vibration frequency [64,71].

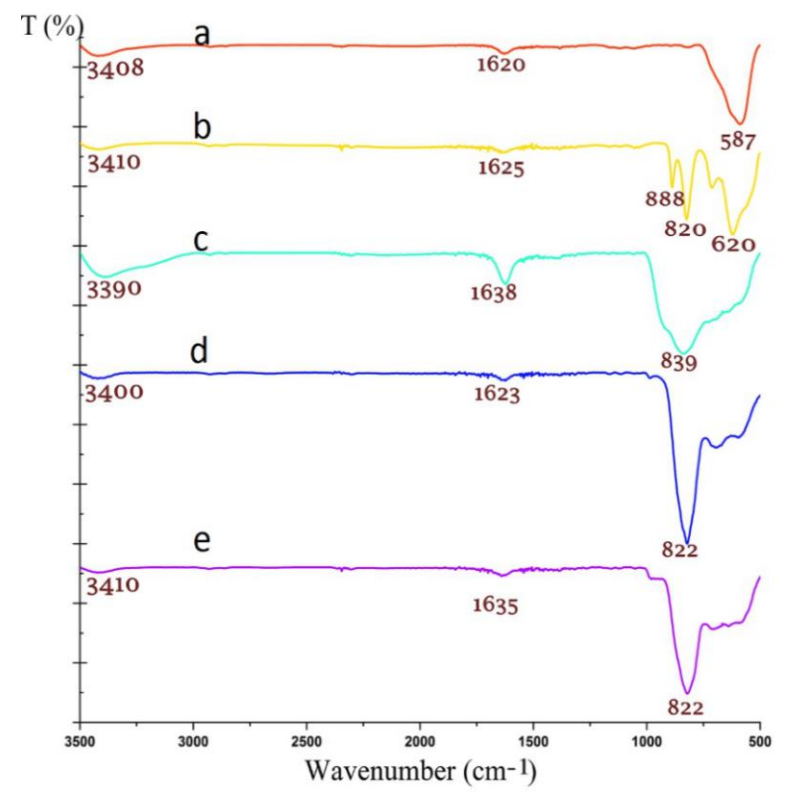

Figure 5. FTIR spectra of (a) $\mathrm{Fe}_{3} \mathrm{O}_{4}$, (b) the $\mathrm{S}_{1}$ sample, (c) the $\mathrm{S}_{4}$ sample before calcination, (d) the $\mathrm{S}_{4}$ sample after calcination, and (e) $\mathrm{S}_{4}$ after the photodegradation of MB. 
Figure 5e shows the FTIR spectrum of $\mathrm{S}_{4}$ after the photodegradation of MB (25 ppm) upon irradiation with UV light. The lack of change in the peak indicates that the photocatalyst was not altered during the photocatalytic reaction. Based on the FTIR data, light irradiation in the presence of organic pollutants did not affect or destroy the chemical structure of the obtained inorganic nanoparticles. Therefore, the FTIR studies confirmed the incorporation of the three inorganic phases into one system and their high environmental stability under light irradiation, indicating that these nanostructures were successfully used as photocatalytic materials to remove pollutants.

\subsection{Photocatalytic Reactions Using $\mathrm{Fe}_{3} \mathrm{O}_{4} / \mathrm{ZnWO} \mathrm{Zn}_{4} / \mathrm{CeVO}_{4}$}

Figure 6a shows the photocatalytic degradation of $25 \mathrm{mg} \mathrm{L}^{-1} \mathrm{MB}$ by the synthesized samples (along with $1 \mathrm{~mL}$ of $\mathrm{H}_{2} \mathrm{O}_{2}$ in $100 \mathrm{~mL}$ of $\mathrm{MB}$ ) to determine an optimal catalyst and compare the performance of $\mathrm{H}_{2} \mathrm{O}_{2}$ in the presence and absence of the catalysts. Additionally, Figure $6 \mathrm{~b}$ shows a plot of the kinetics of $-\ln \left(C / C_{0}\right)$ versus the irradiation time. Figure $6 \mathrm{c}$ shows temporal changes in the absorption spectra of MB during the photodegradation mediated by the $S_{4}$ sample. The slope of the linear regression curve was calculated as the first-order reaction rate constant. As shown in Figure 6a, $\mathrm{S}_{4}$ exhibited the best performance among all synthesized samples and was capable of removing the organic pollutant via photocatalysis.
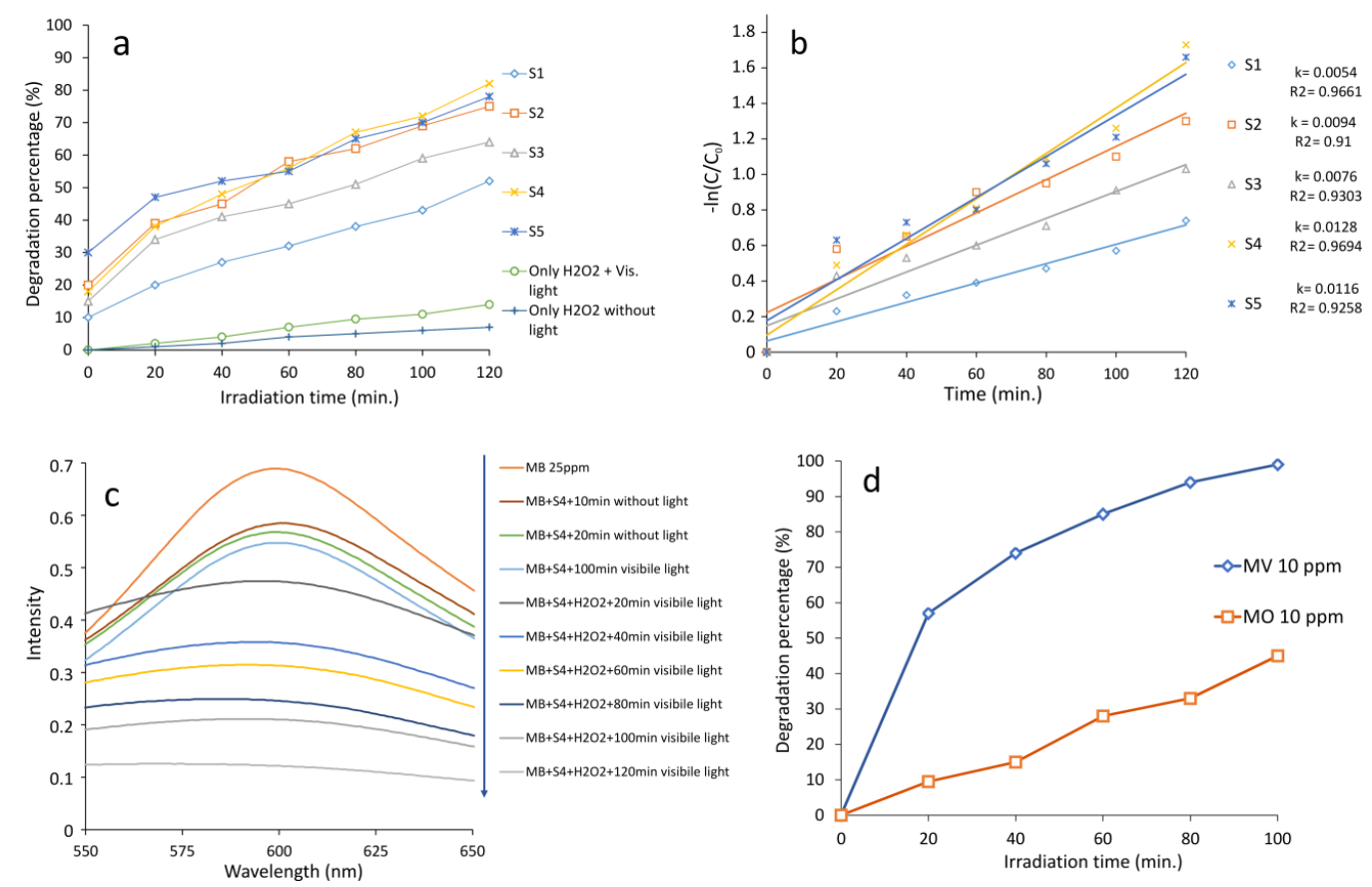

Figure 6. (a) Photocatalytic degradation of $\mathrm{MB}$ (1-5 samples) under visible light assisted by $\mathrm{H}_{2} \mathrm{O}_{2}$. (b) Pseudo-first-order kinetics of MB degradation by samples 1-5. (c) Temporal changes in the absorption spectra of $\mathrm{MB}$ during the photodegradation mediated by the $\mathrm{S}_{4}$ sample. (d) Photocatalytic degradation of the $\mathrm{MV}$ and $\mathrm{MO}$ pollutants by the $\mathrm{S}_{4}$ sample under visible light assisted by $\mathrm{H}_{2} \mathrm{O}_{2}$.

Similar experiments for $\mathrm{S}_{4}$ were conducted to measure the photodegradation of MV and MO, and the results are shown in Figure 6d. The photodegradation of MV was much higher than that of MO. After of exposure to light irradiation for $100 \mathrm{~min}, 90 \%$ of MV was degraded. Similarly, under the same experimental conditions, less $\mathrm{MO}$ was degraded, approximately $50 \%$ of the initial concentration, by the $\mathrm{S}_{4}$ sample.

A photocatalytic degradation test was performed using different contaminants, $\mathrm{MB}, \mathrm{MO}$, fenitrothion (FNT, O,O-dimethyl-O-4-nitro-m-tolyl phosphorothioate), and rhodamine-B (RhB), to examine the photocatalytic efficiency of $S_{4}$ upon irradiation with UV light. The results are shown 
in Figure 7. After approximately $70 \mathrm{~min}$ of exposure to light, the lowest photocatalytic activity of $\mathrm{S}_{4}$ was observed for FNT. This is an organophosphorus pesticide that exhibits high chemical stability and resistance to biodegradation [72,73]. Pesticides degrade very slowly under light irradiation compared with the reaction rates obtained using photocatalysts [74].
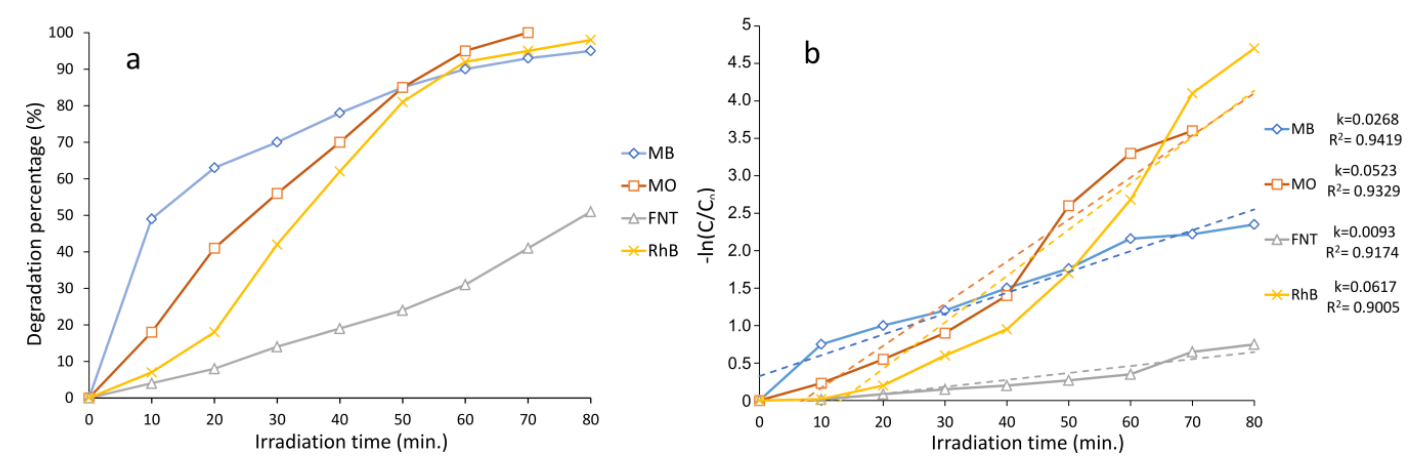

Figure 7. (a) Photocatalytic degradation of $\mathrm{MB}, \mathrm{MO}, \mathrm{FNT}$, and RhB by the $\mathrm{S}_{4}$ sample under UV light irradiation. (b) Pseudo-first-order kinetics of MB, MO, FNT, and RhB degradation by the $\mathrm{S}_{4}$ sample.

The addition of some inorganic and organic matter is necessary to increase the photodegradation efficiency of photocatalysts because these substances may affect the photodegradation rate due to their adsorption on the catalyst surface [75]. On the other hand, efficient photodegradation of MB, MO, and $\mathrm{RhB}$ by $\mathrm{S}_{4}$ was observed.

The mechanisms of photocatalytic reactions were examined by capturing hydroxyl radicals $(\mathrm{OH})$. Hydroxyl radicals are usually sensed with the terephthalic acid (TA) photoluminescence probing method [76-78]. Following the adsorption of ' $\mathrm{OH}$ by TA, 2-hydroxyl-terephthalic acid is produced and displays fluorescence emission; therefore, $\mathrm{OH}$ is able to be sensed by monitoring the changes in the fluorescence intensity of the TA solution. Figure 8 shows the variations in the fluorescence intensity of 2-hydroxyl-terephthalic acid at $443 \mathrm{~nm}$. As shown in Figure 8, with increasing UV irradiation time, the fluorescence intensity increased. However, in the first $10 \mathrm{~min}$ without irradiation, the intensity of the $\mathrm{OH}$ signal was minimized, indicating that ${ }^{\circ} \mathrm{OH}$ was produced over the photocatalyst during UV irradiation.

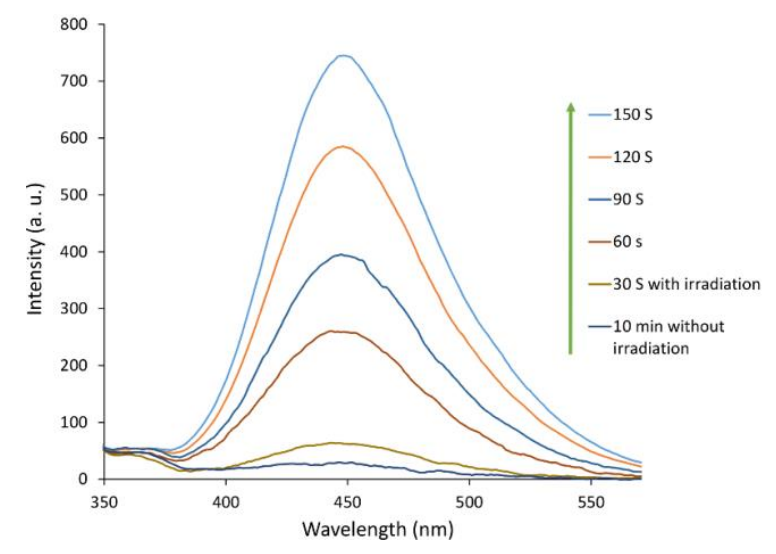

Figure 8. The temporal changes in the fluorescence intensity of 2-hydroxyl-terephthalic acid upon irradiation with UV light $(290 \mathrm{~nm})$ in the presence of $S_{4}$.

The principal oxidative species in the photocatalytic process was identified by performing trapping tests of $\mathrm{OH}$, superoxide radical $\left(\mathrm{O}_{2}{ }^{-}\right)$, and holes using tert-butanol, benzoquinone, and citric acid, respectively $[64,71]$. The results of the experiments conducted using these scavengers to measure the photodegradation of MB (25 ppm) are shown in Figure 9a. After the addition of the 
superoxide scavenger, the photocatalyst performance was substantially reduced (by approximately $75 \%)$. Furthermore, the addition of the hydroxyl scavenger decreased the photocatalytic performance by approximately $50 \%$. In contrast, the addition of the hole scavenger exerted a slight effect on photocatalytic performance. Based on these results, the ${ }^{\circ} \mathrm{OH}$ and ${ }^{~} \mathrm{O}_{2}{ }^{-}$radicals were the main oxidative species photogenerated by the synthesized nanoparticles. Figure $9 \mathrm{~b}$ presents the proposed graphical mechanism of the photocatalytic reaction in the presence of $\mathrm{H}_{2} \mathrm{O}_{2}$. This mechanism was determined and described in detail in our previous study [65].
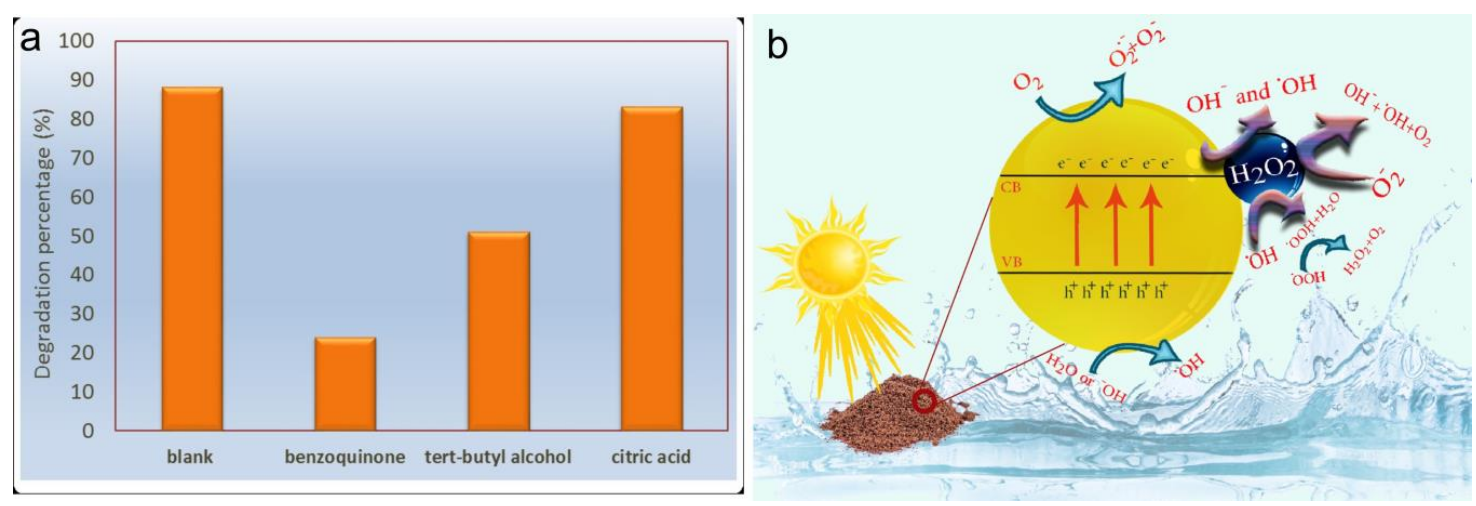

Figure 9. (a) Effects of different scavengers (benzoquinone, tert-butyl alcohol, and citric acid) on the photocatalytic degradation of MB. (b) Proposed graphical mechanism of the photocatalytic reaction.

The photocatalytic activity of semiconductors is very complicated and can be affected by factors such as the chemical structure, composition, material size, surface area, and a suitable band gap. Briefly, considering a magnetic nanoparticle as a photocatalyst, the magnetic core is useful for the separation of the photocatalyst from treated water whereas the outer inorganic layer is beneficial for the photocatalytic reaction [44]. Some examples of $\mathrm{Fe}_{3} \mathrm{O}_{4}$-based photocatalysts are presented in Table 2 .

Table 2. Some examples of $\mathrm{Fe}_{3} \mathrm{O}_{4}$-based photocatalysts and their photocatalytic parameters.

\begin{tabular}{|c|c|c|c|c|c|c|}
\hline Samples & $\begin{array}{l}\text { Light } \\
\text { Source }\end{array}$ & Pollutant & $\begin{array}{c}\text { Degradation } \\
(\%)\end{array}$ & $\begin{array}{l}\text { The Amount of } \\
\text { Catalyst Used } \\
(\mathrm{g} / 100 \mathrm{~mL})\end{array}$ & Time (min) & Ref. \\
\hline $\mathrm{Fe}_{3} \mathrm{O}_{4} / \mathrm{TiO}_{2}(120 \mathrm{~nm})$ & UV & $\mathrm{RhB}$ & 5.4 & 0.1 & 50 & [79] \\
\hline $\mathrm{Fe}_{3} \mathrm{O}_{4} / \mathrm{TiO}_{2}(420 \mathrm{~nm})$ & UV & $\mathrm{RhB}$ & 25.8 & 0.1 & 50 & [79] \\
\hline $\mathrm{Fe}_{3} \mathrm{O}_{4} / \mathrm{ZnWO}_{4}$ & UV & $\mathrm{RhB}$ & 100 & 0.1 & 300 & [80] \\
\hline $\mathrm{Fe}_{3} \mathrm{O}_{4} / \mathrm{Ag}_{2} \mathrm{WO}_{4}$ & Vis. & Fast green & 81 & - & 120 & [81] \\
\hline $\mathrm{Fe}_{3} \mathrm{O}_{4} / \mathrm{CdWO}_{4}$ & Vis. & MB & 32 & 0.02 & 120 & [62] \\
\hline $\mathrm{Fe}_{3} \mathrm{O}_{4} / \mathrm{CdWO}_{4} / \mathrm{PrVO}_{4}$ & Vis. & MB & 68 & 0.02 & 120 & [62] \\
\hline $\mathrm{Bi}_{2} \mathrm{WO}_{6}$ & Vis. & $\mathrm{RhB}$ & 62.5 & - & 180 & [82] \\
\hline $\mathrm{Fe}_{3} \mathrm{O}_{4} / \mathrm{Bi}_{2} \mathrm{WO}_{6}$ & Vis. & $\mathrm{RhB}$ & 95.8 & - & 180 & [82] \\
\hline $\mathrm{Fe}_{3} \mathrm{O}_{4} / \mathrm{Bi}_{2} \mathrm{WO}_{6}$ & Vis. & $\mathrm{RhB}$ & 66 & 0.1 & 180 & [83] \\
\hline $\mathrm{Fe}_{3} \mathrm{O}_{4} / \mathrm{SiO}_{2} / \mathrm{Bi}_{2} \mathrm{WO}_{6}$ & Vis. & $\mathrm{RhB}$ & 100 & - & 100 & [82] \\
\hline $\mathrm{ZnO}$ & UV & MB & 80 & 0.01 & 60 & {$[84]$} \\
\hline $\mathrm{Fe}_{3} \mathrm{O}_{4} / \mathrm{ZnO}$ & UV & MB & 94 & 0.01 & 60 & [84] \\
\hline $\mathrm{Fe}_{3} \mathrm{O}_{4} / \mathrm{Zn}_{\mathrm{x}} \mathrm{Cd}_{1-\mathrm{c}} \mathrm{S}$ & Vis. & MB & 92 & 0.01 & 35 & [85] \\
\hline $\mathrm{Fe}_{3} \mathrm{O}_{4} / \mathrm{ZnWO}_{4} / \mathrm{CeVO}_{4}$ & Vis & MB & 84 & 0.02 & 120 & This work \\
\hline
\end{tabular}

Application of pristine $\mathrm{Fe}_{3} \mathrm{O}_{4}$ in photocatalysis is limited owing to its easy aggregation and its easy electron-hole recombination [44]. To eliminate these shortcomings, the modification of $\mathrm{Fe}_{3} \mathrm{O}_{4}$ is required by designing core-shell nanostructures (Table 2). The $\mathrm{Fe}_{3} \mathrm{O}_{4}$-based nanocomposites have higher chemical and photochemical stability, higher photocatalytic activity, and are reusable and magnetically recoverable. For example, introducing inert substances, such as ceramics $\left(\mathrm{SiO}_{2}\right)$, can protect $\mathrm{Fe}_{3} \mathrm{O}_{4}$ from chemical dissolution and can affect photocatalytic processes [79]. By controlling the thickness of the outer inorganic shell, increased degradation of pollutants might be achieved [80]. 
The smaller photocatalytic nanoparticles are more active than larger ones. With decreasing size of the semiconductor crystal size, the recombination rate of $e^{-} / h^{+}$pairs will decrease [67]. Additionally, smaller nanoparticles with larger specific areas have a higher photon absorption rate on the surface of photons. These findings were observed for our $\mathrm{Fe}_{3} \mathrm{O}_{4} / \mathrm{ZnWO}_{4} / \mathrm{CeVO}_{4}$ nanoparticles with the different molar ratios of the three components (Figure 2). Briefly, comparison of the pristine inorganic nanoparticles with the nanocomposites clearly showed that the improved photocatalytic activity of the multilayered nanoparticles was ascribed to efficient electron-hole separation.

In summary, we suggest that the synergetic effect of triple-layer inorganic nanoparticles $\left(\mathrm{Fe}_{3} \mathrm{O}_{4}\right.$ and $\mathrm{ZnWO}_{4}$ and $\mathrm{CeVO}_{4}$ ) leads to enhancement of photocatalytic activity under visible light irradiation (Table 2). In this regard, the $\mathrm{Fe}_{3} \mathrm{O}_{4} / \mathrm{ZnWO}_{4} / \mathrm{CeVO}_{4}$ nanoparticles (with molar ratios of 1:2:1) are found to be effective as a simple recyclable photocatalytic material for removing organic pollutants from wastewater.

\section{Materials and Methods}

\subsection{Materials}

Unless noted, all chemicals and solvents were commercially available and used as received without further purification from Sigma, Germany. We used iron (III) chloride hexahydrate $\left(\mathrm{FeCl}_{3} \cdot 6 \mathrm{H}_{2} \mathrm{O}\right)$ $(99 \%)$, iron (II) chloride tetrahydrate $\left(\mathrm{FeCl}_{2} \cdot 4 \mathrm{H}_{2} \mathrm{O}\right)(99 \%)$, sodium hydroxide $(\mathrm{NaOH})(98 \%)$, zinc chloride $\left(\mathrm{ZnCl}_{2}\right)(98 \%)$, zinc tungstate $\left(\mathrm{ZnWO}_{4}\right)(99 \%)$, sodium tungstate dehydrate $\left(\mathrm{Na}_{2} \mathrm{WO}_{4} \cdot 2 \mathrm{H}_{2} \mathrm{O}\right)$ $(99 \%)$, cerium (III) nitrate hexahydrate $\left(\mathrm{Ce}\left(\mathrm{NO}_{3}\right)_{3} \cdot 6 \mathrm{H}_{2} \mathrm{O}\right)(99 \%)$, ammonium metavanadate $\left(\mathrm{NH}_{4} \mathrm{VO}_{3}\right)$ (99\%), methyl orange (MO) (99\%), methylene blue (MB) (99\%), methyl violet (MV) $(99 \%)$, fenitrothion (FNT) (99\%), rhodamine B (RhB) (99\%) and ethanol (99.8\%). All aqueous solutions were made using deionized water, which was further purified with a Milli-Q system (Millipore).

\subsection{Synthesis of $\mathrm{Fe}_{3} \mathrm{O}_{4}$ Nanoparticles}

The co-precipitation method was used to synthesize the $\mathrm{Fe}_{3} \mathrm{O}_{4}$ nanoparticles. First, $16.25 \mathrm{~g}$ of $\mathrm{FeCl}_{3}$ and $6.32 \mathrm{~g}$ of $\mathrm{FeCl}_{2}$ were dissolved in $200 \mathrm{~mL}$ of distilled water and stirred with a mechanical stirrer for $60 \mathrm{~min}$. Then, precipitation was induced by adding $2 \mathrm{M} \mathrm{NaOH}$ at $30^{\circ} \mathrm{C}$ in an $\mathrm{N}_{2}$ atmosphere. The reaction system was maintained at a temperature of $70^{\circ} \mathrm{C}$ for $5 \mathrm{~h}$, while maintaining the $\mathrm{pH}$ of the solution at \pm 12 . Next, the system was cooled to room temperature, and the precipitate was separated with a permanent magnet and washed with distilled water to obtain a neutral $\mathrm{pH}$. Finally, $\mathrm{Fe}_{3} \mathrm{O}_{4}$ nanoparticles were washed with acetone and dried at $70{ }^{\circ} \mathrm{C}$ [58].

\subsection{Synthesis of $\mathrm{Fe}_{3} \mathrm{O}_{4} / \mathrm{ZnWO}_{4}$ Nanoparticles}

The $\mathrm{Fe}_{3} \mathrm{O}_{4} / \mathrm{ZnWO}_{4}$ nanoparticles were synthesized using the in situ co-precipitation method. First, $0.232 \mathrm{~g}$ of the previously obtained $\mathrm{Fe}_{3} \mathrm{O}_{4}$ nanoparticles were dispersed in $50 \mathrm{~mL}$ of distilled water using ultrasonication for $20 \mathrm{~min}$. Then, $0.274 \mathrm{~g}$ of $\mathrm{ZnCl}_{2}$ dissolved in $50 \mathrm{~mL}$ of distilled water was added to the reactor containing $\mathrm{Fe}_{3} \mathrm{O}_{4}$. The reaction mixture was stirred for $10 \mathrm{~min}$ at room temperature using a mechanical stirrer. Then, a solution prepared by dissolving $0.66 \mathrm{~g}$ of $\mathrm{Na}_{2} \mathrm{WO}_{4} \cdot 2 \mathrm{H}_{2} \mathrm{O}$ in $50 \mathrm{~mL}$ of distilled water was added to this mixture dropwise over $10 \mathrm{~min}$, and the whole solution was mixed using ultrasonication. The resulting precipitate was filtered/separated with a magnet, washed twice with distilled water and once with ethanol, and dried in an oven at $70{ }^{\circ} \mathrm{C}$. Finally, the synthesized $\mathrm{Fe}_{3} \mathrm{O}_{4} / \mathrm{ZnWO}_{4}$ nanoparticles were placed in an oven for calcination $\left(3 \mathrm{~h}\right.$ at $\left.550{ }^{\circ} \mathrm{C}\right)$.

\subsection{Synthesis of $\mathrm{Fe}_{3} \mathrm{O}_{4} / \mathrm{ZnWO}_{4} / \mathrm{CeVO}_{4}$ Nanoparticles}

For this reaction, $0.544 \mathrm{~g}$ of $\mathrm{Fe}_{3} \mathrm{O}_{4} / \mathrm{ZnWO}_{4}$ prepared in the previous step was dispersed in $50 \mathrm{~mL}$ of distilled water and ultrasonicated for $20 \mathrm{~min}$. Then, $0.058 \mathrm{~g}$ of $\mathrm{NH}_{4} \mathrm{VO}_{3}$ and $0.217 \mathrm{~g}$ of $\mathrm{Ce}\left(\mathrm{NO}_{3}\right)_{3} \cdot 6 \mathrm{H}_{2} \mathrm{O}$, were separately dissolved in $50 \mathrm{~mL}$ of distilled water to prepare a precipitate with a molar ratio of 1:2:0.5. The $\mathrm{NH}_{4} \mathrm{VO}_{3}$ solution was added to the previously dispersed nanoparticles. The mixture was 
subjected to ultrasonication with a probe with a power of $400 \mathrm{~W}$ and frequency of $20 \mathrm{KHz}$. Afterwards, the $\mathrm{Ce}\left(\mathrm{NO}_{3}\right)_{3} \cdot 6 \mathrm{H}_{2} \mathrm{O}$ solution was added dropwise to the mixture, and the reaction continued for the next 15 min. Quantities of $0.087 \mathrm{~g}$ of $\mathrm{NH}_{4} \mathrm{VO}_{3}$ and $0.325 \mathrm{~g}$ of $\mathrm{Ce}\left(\mathrm{NO}_{3}\right)_{3} \cdot 6 \mathrm{H}_{2} \mathrm{O}, 0.117 \mathrm{~g}$ of $\mathrm{NH}_{4} \mathrm{VO}_{3}$, and $0.44 \mathrm{~g}$ of $\mathrm{Ce}\left(\mathrm{NO}_{3}\right)_{3} \cdot 6 \mathrm{H}_{2} \mathrm{O}$, as well as $0.175 \mathrm{~g}$ of $\mathrm{NH}_{4} \mathrm{VO}_{3}$ and $0.651 \mathrm{~g}$ of $\mathrm{Ce}\left(\mathrm{NO}_{3}\right)_{3} \cdot 6 \mathrm{H}_{2} \mathrm{O}$, were used to prepare precipitates with molar ratios of 1:2:0.75, 1:2:1, and 1:2:1.5, respectively. The obtained precipitates were washed twice with distilled water and once with ethanol and then dried in an oven at $70{ }^{\circ} \mathrm{C}$. Finally, the synthesized $\mathrm{Fe}_{3} \mathrm{O}_{4} / \mathrm{ZnWO}_{4} / \mathrm{CeVO}_{4}$ nanoparticles were placed in an oven for calcination $\left(3 \mathrm{~h}\right.$ at $\left.550{ }^{\circ} \mathrm{C}\right)$.

\subsection{Evaluation of Photocatalytic Activities}

The photodegradation of MB under visible light was measured for all synthesized samples to choose the nanoparticles with the highest photocatalytic activity. In each experiment, $60 \mathrm{mg}$ of photocatalyst was added to $300 \mathrm{~mL}$ of a $25 \mathrm{mg} \mathrm{L}^{-1} \mathrm{MB}$ solution. Three milliliters of $25 \% \mathrm{H}_{2} \mathrm{O}_{2}$ were added to the photoreactor to increase the efficacy. Prior to exposure to visible light ( $250 \mathrm{~W}$ xenon lamp), the solution was stirred in the dark for $20 \mathrm{~min}$ to obtain an adsorption/desorption equilibrium between the catalyst and MB. Four milliliters of the solution were collected with a pipette every $10 \mathrm{~min}$ for the reaction conducted in the dark and every $20 \mathrm{~min}$ for the reaction conducted in the light. Then, the studied solution was centrifuged at $5000 \mathrm{rpm}$ for $5 \mathrm{~min}$ to separate the catalyst. The concentration of the MB solution was calculated by recording the absorption with a UV-Vis spectrophotometer to identify the result of the photodegradation of pollutants. Afterwards, the sample with the optimized photocatalytic properties (the highest value of degradation) was used for the photodegradation of $10 \mathrm{mg} \mathrm{L}^{-1} \mathrm{MO}$ and $10 \mathrm{mg} \mathrm{L}^{-1} \mathrm{MV}$.

The photocatalytic activity of $\mathrm{S}_{4}$ was evaluated by analyzing the photodegradation of MB under UV light to determine the efficiency of the synthesized photocatalyst. In each experiment, $30 \mathrm{mg}$ of photocatalyst was added to $300 \mathrm{~mL}$ of the $20 \mathrm{mg} / \mathrm{L} \mathrm{MB}$ solution. Prior to exposure to the UV light, (50 W Hg lamp), the solution was stirred in the dark for $20 \mathrm{~min}$ to obtain an adsorption/desorption equilibrium between the catalyst and MB solution. Next, $4 \mathrm{~mL}$ of the solution were pipetted every $10 \mathrm{~min}$ and centrifuged at $5000 \mathrm{rpm}$ for $5 \mathrm{~min}$ to separate the catalyst. As described above, the concentration of the MB solution was calculated by measuring the absorbance with a UV-Vis spectrophotometer to estimate the yield of photodegradation. Afterwards, the material with the optimal photocatalytic properties was used to photodegrade $15 \mathrm{mg} \mathrm{L}^{-1} \mathrm{MO}, 15 \mathrm{mg} \mathrm{L}^{-1} \mathrm{FNT}$, and $20 \mathrm{mg} \mathrm{L}^{-1} \mathrm{RhB}$.

\subsection{Photodegradation Mechanism}

The release of ' $\mathrm{OH}$ was measured using a photoluminescence method. 2-Hydroxyterephthalic acid is the product of the reaction of TA with $\mathrm{OH}$, which has fluorescence properties. Hence, the fluorescence intensity depends on the amount of ${ }^{\circ} \mathrm{OH}$ released. The method is similar to photocatalytic tests conducted under UV light. The solution was prepared by adding $0.03 \mathrm{~g}$ of the synthesized catalyst $\left(0.1 \mathrm{~g} \mathrm{~L}^{-1}\right)$ to $300 \mathrm{~mL}$ of the aqueous TA solutions prepared at concentrations of $0.0005 \mathrm{M}$ and $0.002 \mathrm{M}$ in $\mathrm{NaOH}$. The principal oxidative factor in the photocatalytic reactions was identified by measuring the amounts of $\mathrm{O}_{2}{ }^{-}, \mathrm{OH}$, and holes trapped by tert-butanol, benzoquinone, and citric acid, respectively. The procedure is similar to the UV irradiation test. Three hundred milliliters of a $25 \mathrm{mg} \mathrm{L}^{-1} \mathrm{MB}$ solution were prepared, and then $3 \mathrm{mmol}$ of one of the scavengers were added to that solution. Afterwards, $0.03 \mathrm{~g}$ of dispersed photocatalyst was added to the system. Finally, after exposing the solution to UV light, $4 \mathrm{~mL}$ of the solution was removed from the reactor every $10 \mathrm{~min}$ and the catalyst was separated from the pollutant by centrifugation. The progress of each reaction was monitored using a UV-Vis spectrophotometer.

\section{Conclusions}

The $\mathrm{Fe}_{3} \mathrm{O}_{4} / \mathrm{ZnWO}_{4} / \mathrm{CeVO}_{4}$ nanoparticles were prepared at different molar ratios using the co-precipitation method with the help of the sonochemical method. Identification tests, such as 
XRD, SEM, FTIR, and EDX, confirmed the presence of the subsequent inorganic phases: $\mathrm{Fe}_{3} \mathrm{O}_{4}$, $\mathrm{ZnWO}_{4}$, and $\mathrm{CeVO}_{4}$. The VSM test allowed us to calculate the MS values for $\mathrm{Fe}_{3} \mathrm{O}_{4}$ and the $\mathrm{Fe}_{3} \mathrm{O}_{4} / \mathrm{ZnWO}_{4} / \mathrm{CeVO}_{4}$ nanoparticles: 50.9 and $1.5 \mathrm{emu} \mathrm{g}{ }^{-1}$, respectively. Additionally, based on the results of the DRS test, the OBGEs for $\mathrm{Fe}_{3} \mathrm{O}_{4}$ and $\mathrm{Fe}_{3} \mathrm{O}_{4} / \mathrm{ZnWO}_{4} / \mathrm{CeVO}_{4}$ were 3.1 and $2.6 \mathrm{eV}$, respectively. The $\mathrm{Fe}_{3} \mathrm{O}_{4} / \mathrm{ZnWO}_{4} / \mathrm{CeVO}_{4}$ nanoparticles with a 1:2:1 molar ratio mediated the highly efficient photocatalytic degradation of different organic pollutants, such as MV with $\sim 100 \%$ degradation (with visible light) and $\mathrm{MO}$ with $\sim 100 \%$ degradation (under $\mathrm{UV}$ light). When $\mathrm{Fe}_{3} \mathrm{O}_{4} / \mathrm{ZnWO}_{4} / \mathrm{CeVO}_{4}$ $\left(\mathrm{S}_{4}\right)$ was reacted in the presence of various scavengers, the photogenerated $\mathrm{OH}$ and ${ }^{\circ} \mathrm{O}_{2}{ }^{-}$radicals were the main oxidative forms, and the fluorescence intensities increased over time upon the irradiation of TA with UV-Vis light, which produced $\mathrm{OH}$ as a by-product. These results confirm that the $\mathrm{Fe}_{3} \mathrm{O}_{4} / \mathrm{ZnWO}_{4} / \mathrm{CeVO}_{4}$ nanoparticles represent a potentially useful photocatalyst for the effective removal of organic pollutants from wastewater.

Author Contributions: Conceptualization, M.A.M., M.R.N., and A.S.N.; statistical analysis, M.A.M., M.R.N., and A.S.N.; writing—original draft preparation, M.A.M, M.R.N., A.S.N., M.F.-R., K.A., S.P., F.A. and M.E.; methodology and writing - review and editing, M.E.P.-B. and M.T.; and funding acquisition, M.R.N., M.E.P.-B., and M.T. All authors approved the final version for submission. All authors have read and agreed to the published version of the manuscript.

Funding: We gratefully acknowledge the financial support from Iran University of Medical Sciences to M.R.N. and from the Ministry of Science and Higher Education, Poland (SUB/2/DN/20/001/2204) to M.E.P.-B. This study was supported by Council of Baqiyatallah University of Medical Sciences through grant agreement No. 95221.

Conflicts of Interest: The authors have no conflicts of interest to declare.

\section{References}

1. Franz, S.; Falletta, E.; Arab, H.; Murgolo, S.; Bestetti, M.; Mascolo, G. Degradation of Carbamazepine by Photo(electro)catalysis on Nanostructured $\mathrm{TiO}_{2}$ Meshes: Transformation Products and Reaction Pathways. Catalysts 2020, 10, 169. [CrossRef]

2. Li, S.; Xue, B.; Chen, J.; Jiang, W.; Liu, Y. BiOCOOH Microflowers Decorated with $\mathrm{Ag} / \mathrm{Ag}_{2} \mathrm{CrO}_{4}$ Nanoparticles as Highly Efficient Photocatalyst for the Treatment of Toxic Wastewater. Catalysts 2020, 10, 93. [CrossRef]

3. Feijoo, S.; González-Rodríguez, J.; Fernández, L.; Vázquez-Vázquez, C.; Feijoo, G.; Moreira, M.T. Fenton and Photo-Fenton Nanocatalysts Revisited from the Perspective of Life Cycle Assessment. Catalysts 2019, 10, 23. [CrossRef]

4. Włodarczyk, P.P.; Włodarczyk, B. Preparation and Analysis of Ni-Co Catalyst Use for Electricity Production and COD Reduction in Microbial Fuel Cells. Catalysts 2019, 9, 1042. [CrossRef]

5. Khalid, S.; Shahid, M.; Natasha Bibi, I.; Sarwar, T.; Shah, A.; Niazi, N. A Review of Environmental Contamination and Health Risk Assessment of Wastewater Use for Crop Irrigation with a Focus on Low and High-Income Countries. Int. J. Environ. Res. Public Health 2018, 15, 895. [CrossRef]

6. Schaider, L.A.; Rodgers, K.M.; Rudel, R.A. Review of Organic Wastewater Compound Concentrations and Removal in Onsite Wastewater Treatment Systems. Environ. Sci. Technol. 2017, 51, 7304-7317. [CrossRef]

7. Bartolomeu, M.; Neves, M.G.P.M.S.; Faustino, M.A.F.; Almeida, A. Wastewater chemical contaminants: Remediation by advanced oxidation processes. Photochem. Photobiol. Sci. 2018, 17, 1573-1598. [CrossRef]

8. Holkar, C.R.; Jadhav, A.J.; Pinjari, D.V.; Mahamuni, N.M.; Pandit, A.B. A critical review on textile wastewater treatments: Possible approaches. J. Environ. Manag. 2016, 182, 351-366. [CrossRef]

9. Kweinor Tetteh, E.; Rathilal, S.; Chetty, M.; Kwaku Armah, E.; Asante-Sackey, D. Treatment of Water and Wastewater for Reuse and Energy Generation-Emerging Technologies. In Water and Wastewater Treatment; Eyvaz, M., Ed.; IntechOpen: London, UK, 2019; ISBN 978-1-78923-929-4.

10. Singh, N.B.; Nagpal, G.; Agrawal, S. Rachna Water purification by using Adsorbents: A Review. Environ. Technol. Innov. 2018, 11, 187-240. [CrossRef]

11. Eghbali-Arani, M.; Sobhani-Nasab, A.; Rahimi-Nasrabadi, M.; Pourmasoud, S. Green Synthesis and Characterization of $\mathrm{SmVO}_{4}$ Nanoparticles in the Presence of Carbohydrates as Capping Agents with Investigation of Visible-Light Photocatalytic Properties. J. Electron. Mater. 2018, 47, 3757-3769. [CrossRef] 
12. Zinatloo-Ajabshir, S.; Mortazavi-Derazkola, S.; Salavati-Niasari, M. Preparation, characterization and photocatalytic degradation of methyl violet pollutant of holmium oxide nanostructures prepared through a facile precipitation method. J. Mol. Liq. 2017, 231, 306-313. [CrossRef]

13. Shon, J.-H.; Teets, T.S. Photocatalysis with Transition Metal Based Photosensitizers. Comments Inorg. Chem. 2020, 40, 53-85. [CrossRef]

14. Xu, C.; Ravi Anusuyadevi, P.; Aymonier, C.; Luque, R.; Marre, S. Nanostructured materials for photocatalysis. Chem. Soc. Rev. 2019, 48, 3868-3902. [CrossRef]

15. Luciani, G.; Imparato, C.; Vitiello, G. Photosensitive Hybrid Nanostructured Materials: The Big Challenges for Sunlight Capture. Catalysts 2020, 10, 103. [CrossRef]

16. Fujishima, A.; Honda, K. Electrochemical Photolysis of Water at a Semiconductor Electrode. Nature 1972, 238, 37-38. [CrossRef] [PubMed]

17. Xiang, Q.; Yu, J.; Jaroniec, M. Graphene-based semiconductor photocatalysts. Chem. Soc. Rev. 2012, 41, 782-796. [CrossRef] [PubMed]

18. Wang, H.; Zhang, L.; Chen, Z.; Hu, J.; Li, S.; Wang, Z.; Liu, J.; Wang, X. Semiconductor heterojunction photocatalysts: Design, construction, and photocatalytic performances. Chem. Soc. Rev. 2014, 43, 5234. [CrossRef]

19. Chen, X.; Shen, S.; Guo, L.; Mao, S.S. Semiconductor-based Photocatalytic Hydrogen Generation. Chem. Rev. 2010, 110, 6503-6570. [CrossRef]

20. Hisatomi, T.; Kubota, J.; Domen, K. Recent advances in semiconductors for photocatalytic and photoelectrochemical water splitting. Chem. Soc. Rev. 2014, 43, 7520-7535. [CrossRef]

21. Chen, Y.; Bai, X. A Review on Quantum Dots Modified g- $\mathrm{C}_{3} \mathrm{~N}_{4}$-Based Photocatalysts with Improved Photocatalytic Activity. Catalysts 2020, 10, 142. [CrossRef]

22. Zhang, L.; Ran, J.; Qiao, S.-Z.; Jaroniec, M. Characterization of semiconductor photocatalysts. Chem. Soc. Rev. 2019, 48, 5184-5206. [CrossRef] [PubMed]

23. Moreno-Castilla, C.; López-Ramón, M.V.; Fontecha-Cámara, M.Á.; Álvarez, M.A.; Mateus, L. Removal of Phenolic Compounds from Water Using Copper Ferrite Nanosphere Composites as Fenton Catalysts. Nanomaterials 2019, 9, 901. [CrossRef] [PubMed]

24. Lv, J.; Dai, K.; Zhang, J.; Lu, L.; Liang, C.; Geng, L.; Wang, Z.; Yuan, G.; Zhu, G. In situ controllable synthesis of novel surface plasmon resonance-enhanced $\mathrm{Ag}_{2} \mathrm{WO}_{4} / \mathrm{Ag} / \mathrm{Bi}_{2} \mathrm{MoO}_{6}$ composite for enhanced and stable visible light photocatalyst. Appl. Surf. Sci. 2017, 391, 507-515. [CrossRef]

25. Sobhani-Nasab, A.; Pourmasoud, S.; Ahmadi, F.; Wysokowski, M.; Jesionowski, T.; Ehrlich, H.; Rahimi-Nasrabadi, M. Synthesis and characterization of $\mathrm{MnWO}_{4} / \mathrm{TmVO}_{4}$ ternary nano-hybrids by an ultrasonic method for enhanced photocatalytic activity in the degradation of organic dyes. Mater. Lett. 2019, 238, 159-162. [CrossRef]

26. Peymani-Motlagh, S.M.; Moeinian, N.; Rostami, M.; Fasihi-Ramandi, M.; Sobhani-Nasab, A.; Rahimi-Nasrabadi, M.; Eghbali-Arani, M.; Ganjali, M.R.; Jesionowski, T.; Ehrlich, H.; et al. Effect of Gd3+-, Pr3+- or Sm3+-substituted cobalt-zinc ferrite on photodegradation of methyl orange and cytotoxicity tests. J. Rare Earths 2019, 37, 1288-1295. [CrossRef]

27. Gandomi, F.; Peymani-Motlagh, S.M.; Rostami, M.; Sobhani-Nasab, A.; Fasihi-Ramandi, M.; Eghbali-Arani, M.; Ahmadian, R.; Gholipour, N.; Rahimi-Nasrabadi, M.; Ganjali, M.R. Simple synthesis and characterization of $\mathrm{Li}_{0.5} \mathrm{Fe}_{2.5} \mathrm{O}_{4}, \mathrm{LiMg}_{0.5} \mathrm{Fe}_{2} \mathrm{O}_{4}$ and $\mathrm{LiNi}_{0.5} \mathrm{Fe}_{2} \mathrm{O}_{4}$, and investigation of their photocatalytic and anticancer properties on hela cells line. J. Mater. Sci. Mater. Electron. 2019, 30, 19691-19702. [CrossRef]

28. Chiu, Y.-H.; Chang, T.-F.M.; Chen, C.-Y.; Sone, M.; Hsu, Y.-J. Mechanistic Insights into Photodegradation of Organic Dyes Using Heterostructure Photocatalysts. Catalysts 2019, 9, 430. [CrossRef]

29. Wang, Q.; Nakabayashi, M.; Hisatomi, T.; Sun, S.; Akiyama, S.; Wang, Z.; Pan, Z.; Xiao, X.; Watanabe, T.; Yamada, T.; et al. Oxysulfide photocatalyst for visible-light-driven overall water splitting. Nat. Mater. 2019, 18, 827-832. [CrossRef]

30. Zhang, G.; Wang, X. Oxysulfide Semiconductors for Photocatalytic Overall Water Splitting with Visible Light. Angew. Chem. Int. Ed. 2019, 58, 15580-15582. [CrossRef]

31. Hao, H.; Lang, X. Metal Sulfide Photocatalysis: Visible-Light-Induced Organic Transformations. ChemCatChem 2019, 11, 1378-1393. [CrossRef]

32. Ahmed, M.; Xinxin, G. A review of metal oxynitrides for photocatalysis. Inorg. Chem. Front. 2016, 3, 578-590. [CrossRef] 
33. Polo, A.M.S.; Lopez-Peñalver, J.J.; Sánchez-Polo, M.; Rivera-Utrilla, J.; López-Ramón, M.V.; Rozalén, M. Halide removal from water using silver doped magnetic-microparticles. J. Environ. Manag. 2020, 253, 109731. [CrossRef] [PubMed]

34. Wang, K.; Janczarek, M.; Wei, Z.; Raja-Mogan, T.; Endo-Kimura, M.; Khedr, T.M.; Ohtani, B.; Kowalska, E. Morphology- and Crystalline Composition-Governed Activity of Titania-Based Photocatalysts: Overview and Perspective. Catalysts 2019, 9, 1054. [CrossRef]

35. Melinte, V.; Stroea, L.; Chibac-Scutaru, A.L. Polymer Nanocomposites for Photocatalytic Applications. Catalysts 2019, 9, 986. [CrossRef]

36. Kar, A.; Sain, S.; Kundu, S.; Bhattacharyya, A.; Kumar Pradhan, S.; Patra, A. Influence of Size and Shape on the Photocatalytic Properties of $\mathrm{SnO}_{2}$ Nanocrystals. ChemPhysChem 2015, 16, 1017-1025. [CrossRef] [PubMed]

37. Pereira, P.F.S.; Gouveia, A.F.; Assis, M.; de Oliveira, R.C.; Pinatti, I.M.; Penha, M.; Gonçalves, R.F.; Gracia, L.; Andrés, J.; Longo, E. ZnWO nanocrystals: Synthesis, morphology, photoluminescence and photocatalytic properties. Phys. Chem. Chem. Phys. 2018, 20, 1923-1937. [CrossRef]

38. Zhang, W. Preparation, morphology, size quantization effect and photocatalytic properties of CdS Q-nanocrystals. Sci. China Ser. B 2003, 46, 196-206. [CrossRef]

39. Li, Y.-F.; Liu, Z.-P. Particle Size, Shape and Activity for Photocatalysis on Titania Anatase Nanoparticles in Aqueous Surroundings. J. Am. Chem. Soc. 2011, 133, 15743-15752. [CrossRef] [PubMed]

40. Jin, H.; Tian, X.; Nie, Y.; Zhou, Z.; Yang, C.; Li, Y.; Lu, L. Oxygen Vacancy Promoted Heterogeneous Fenton-like Degradation of Ofloxacin at $\mathrm{pH}$ 3.2-9.0 by Cu Substituted Magnetic $\mathrm{Fe}_{3} \mathrm{O}_{4} @ \mathrm{FeOOH}$ Nanocomposite. Environ. Sci. Technol. 2017, 51, 12699-12706. [CrossRef]

41. Lu, Z.; Zhao, X.; Zhu, Z.; Yan, Y.; Shi, W.; Dong, H.; Ma, Z.; Gao, N.; Wang, Y.; Huang, H. Enhanced Recyclability, Stability, and Selectivity of CdS/C@ $\mathrm{Fe}_{3} \mathrm{O}_{4}$ Nanoreactors for Orientation Photodegradation of Ciprofloxacin. Chem. Eur. J. 2015, 21, 18528-18533. [CrossRef]

42. Hou, X.; Wang, X.; Mi, W. Progress in $\mathrm{Fe}_{3} \mathrm{O}_{4}$-based multiferroic heterostructures. J. Alloys Compd. 2018, 765, 1127-1138. [CrossRef]

43. $\mathrm{Mu}$, Q.; Sun, Y.; Guo, A.; Yu, X.; Xu, X.; Cai, A.; Wang, X. Bio-templated synthesis of $\mathrm{Fe}_{3} \mathrm{O}_{4}-\mathrm{TiO}_{2}$ composites derived from Chlorella pyrenoidosa with enhanced visible-light photocatalytic performance. Mater. Res. Express 2019, 6, 0950c3. [CrossRef]

44. Mishra, P.; Patnaik, S.; Parida, K. An overview of recent progress on noble metal modified magnetic $\mathrm{Fe}_{3} \mathrm{O}_{4}$ for photocatalytic pollutant degradation and $\mathrm{H}_{2}$ evolution. Catal. Sci. Technol. 2019, 9, 916-941. [CrossRef]

45. Amin Marsooli, M.; Rahimi Nasrabadi, M.; Fasihi-Ramandi, M.; Adib, K.; Eghbali, M.; Pourmasoud, S.; Ahmadi, F.; Sohouli, E.; Sobhani Nasab, A.; Ali Mirhosseini, S.; et al. Preparation of $\mathrm{Fe}_{3} \mathrm{O}_{4} / \mathrm{SiO}_{2} / \mathrm{TiO}_{2} / \mathrm{PrVO}_{4}$ nanocomposite in various molar ratios: Investigation on photocatalytic performance on organic contaminate and bacterial environments, and anti-cancer properties. Polyhedron 2020, 176, 114239. [CrossRef]

46. Ke, J.; Adnan Younis, M.; Kong, Y.; Zhou, H.; Liu, J.; Lei, L.; Hou, Y. Nanostructured Ternary Metal Tungstate-Based Photocatalysts for Environmental Purification and Solar Water Splitting: A Review. Nano-Micro Lett. 2018, 10, 69. [CrossRef]

47. García-Pérez, U.M.; de la Cruz, A.M.; Peral, J. Transition metal tungstates synthesized by co-precipitation method: Basic photocatalytic properties. Electrochim. Acta 2012, 81, 227-232. [CrossRef]

48. Peng, W.; Li, Y.; Zhang, F.; Zhang, G.; Fan, X. Roles of Two-Dimensional Transition Metal Dichalcogenides as Cocatalysts in Photocatalytic Hydrogen Evolution and Environmental Remediation. Ind. Eng. Chem. Res. 2017, 56, 4611-4626. [CrossRef]

49. Zawawi, S.M.M.; Yahya, R.; Hassan, A.; Mahmud, H.E.; Daud, M.N. Structural and optical characterization of metal tungstates $\left(\mathrm{MWO}_{4} ; \mathrm{M}=\mathrm{Ni}, \mathrm{Ba}, \mathrm{Bi}\right)$ synthesized by a sucrose-templated method. Chem. Cent. J. 2013, 7, 80. [CrossRef]

50. Kuzmin, A.; Kalendarev, R.; Kursitis, A.; Purans, J. Confocal spectromicroscopy of amorphous and nanocrystalline tungsten oxide films. J. Non-Cryst. Solids 2007, 353, 1840-1843. [CrossRef]

51. Hosseinpour-Mashkani, S.M.; Maddahfar, M.; Sobhani-Nasab, A. Precipitation Synthesis, Characterization,

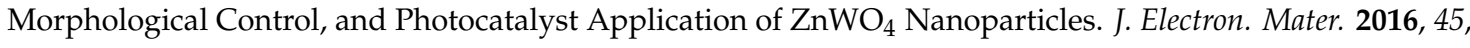
3612-3620. [CrossRef] 
52. Hosseinpour-Mashkani, S.S.; Sobhani-Nasab, A. Investigation the effect of temperature and polymeric capping agents on the size and photocatalytic properties of NdVO4 nanoparticles. J. Mater. Sci. Mater. Electron. 2017, 28, 16459-16466. [CrossRef]

53. Tedstone, A.A.; Lewis, D.J.; O'Brien, P. Synthesis, Properties, and Applications of Transition Metal-Doped Layered Transition Metal Dichalcogenides. Chem. Mater. 2016, 28, 1965-1974. [CrossRef]

54. Lv, R.; Robinson, J.A.; Schaak, R.E.; Sun, D.; Sun, Y.; Mallouk, T.E.; Terrones, M. Transition Metal Dichalcogenides and Beyond: Synthesis, Properties, and Applications of Single- and Few-Layer Nanosheets. Acc. Chem. Res. 2015, 48, 56-64. [CrossRef] [PubMed]

55. Gómez-Pastora, J.; Dominguez, S.; Bringas, E.; Rivero, M.J.; Ortiz, I.; Dionysiou, D.D. Review and perspectives on the use of magnetic nanophotocatalysts (MNPCs) in water treatment. Chem. Eng. J. 2017, 310, 407-427. [CrossRef]

56. Lopez Maldonado, K.L.; de la Presa, P.; de la Rubia, M.A.; Crespo, P.; de Frutos, J.; Hernando, A.; Matutes Aquino, J.A.; Elizalde Galindo, J.T. Effects of grain boundary width and crystallite size on conductivity and magnetic properties of magnetite nanoparticles. J. Nanoparticle Res. 2014, 16, 2482. [CrossRef]

57. Smilgies, D.-M. Scherrer grain-size analysis adapted to grazing-incidence scattering with area detectors. J. Appl. Crystallogr. 2009, 42, 1030-1034. [CrossRef] [PubMed]

58. Zinatloo-Ajabshir, S.; Salavati-Niasari, M. Preparation and characterization of nanocrystalline praseodymium oxide via a simple precipitation approach. J. Mater. Sci. Mater. Electron. 2015, 26, 5812-5821. [CrossRef]

59. Monshi, A.; Foroughi, M.R.; Monshi, M.R. Modified Scherrer Equation to Estimate More Accurately Nano-Crystallite Size Using XRD. World J. Nano Sci. Eng. 2012, 2, 154-160. [CrossRef]

60. Umbrello, D.; Rotella, G.; Matsumura, T.; Musha, Y. Evaluation of microstructural changes by X-ray diffraction peak profile and focused ion beam/scanning ion microscope analysis. Int. J. Adv. Manuf. Technol. 2015, 77, 1465-1474. [CrossRef]

61. Zou, Z.; Xuan, A.G.; Yan, Z.G.; Wu, Y.X.; Li, N. Preparation of $\mathrm{Fe}_{3} \mathrm{O}_{4}$ particles from copper/iron ore cinder and their microwave absorption properties. Chem. Eng. Sci. 2010, 65, 160-164. [CrossRef]

62. Marsooli, M.A.; Fasihi-Ramandi, M.; Adib, K.; Pourmasoud, S.; Ahmadi, F.; Ganjali, M.R.; Sobhani Nasab, A.; Rahimi Nasrabadi, M.; Plonska-Brzezinska, M.E. Preparation and Characterization of Magnetic $\mathrm{Fe}_{3} \mathrm{O}_{4} / \mathrm{CdWO}_{4}$ and $\mathrm{Fe}_{3} \mathrm{O}_{4} / \mathrm{CdWO}_{4} / \mathrm{PrVO}_{4}$ Nanoparticles and Investigation of Their Photocatalytic and Anticancer Properties on PANC1 Cells. Materials 2019, 12, 3274. [CrossRef] [PubMed]

63. Kalai Selvan, R.; Gedanken, A.; Anilkumar, P.; Manikandan, G.; Karunakaran, C. Synthesis and Characterization of Rare Earth Orthovanadate $\left(\mathrm{RVO}_{4} ; \mathrm{R}=\mathrm{La}, \mathrm{Ce}, \mathrm{Nd}, \mathrm{Sm}\right.$, Eu \& Gd) Nanorods/Nanocrystals/ Nanospindles by a Facile Sonochemical Method and Their Catalytic Properties. J. Clust. Sci. 2009, 20, 291-305.

64. Ekthammathat, N.; Thongtem, T.; Phuruangrat, A.; Thongtem, S. Synthesis and Characterization of $\mathrm{CeVO}_{4}$ by Microwave Radiation Method and Its Photocatalytic Activity. J. Nanomater. 2013, 2013, 1-7.

65. Adib, K.; Rezvani, Z.; Rahimi-Nasrabadi, M.; Pourmortazavi, S.M. Statistically optimized synthesis of cadmium tungstate nanoplates for use as a photocatalyst. J. Mater. Sci. Mater. Electron. 2018, 29, 6377-6387. [CrossRef]

66. Beshkar, F.; Zinatloo-Ajabshir, S.; Salavati-Niasari, M. Preparation and characterization of the $\mathrm{CuCr}_{2} \mathrm{O}_{4}$ nanostructures via a new simple route. J. Mater. Sci. Mater. Electron. 2015, 26, 5043-5051. [CrossRef]

67. Deotale, A.J.; Nandedkar, R.V. Correlation between Particle Size, Strain and Band Gap of Iron Oxide Nanoparticles. Mater. Today Proc. 2016, 3, 2069-2076. [CrossRef]

68. Xi, G.; Yue, B.; Cao, J.; Ye, J. Fe3O4/WO3 Hierarchical Core-Shell Structure: High-Performance and Recyclable Visible-Light Photocatalysis. Chem. Eur. J. 2011, 17, 5145-5154. [CrossRef]

69. Yang, S.; Zeng, T.; Li, Y.; Liu, J.; Chen, Q.; Zhou, J.; Ye, Y.; Tang, B. Preparation of Graphene Oxide Decorated $\mathrm{Fe}_{3} \mathrm{O}_{4} @ \mathrm{SiO}_{2}$ Nanocomposites with Superior Adsorption Capacity and SERS Detection for Organic Dyes. J. Nanomater. 2015, 2015, 1-8.

70. Rahimi-Nasrabadi, M.; Pourmortazavi, S.M.; Ganjali, M.R.; Hajimirsadeghi, S.S.; Zahedi, M.M. Electrosynthesis and characterization of zinc tungstate nanoparticles. J. Mol. Struct. 2013, 1047, 31-36. [CrossRef]

71. Sadiq Mohamed, M.J.; Bhat Denthaje, K. Novel RGO-ZnWO $4-\mathrm{Fe}_{3} \mathrm{O}_{4}$ Nanocomposite as an Efficient Catalyst for Rapid Reduction of 4-Nitrophenol to 4-Aminophenol. Ind. Eng. Chem. Res. 2016, 55, 7267-7272. [CrossRef] 
72. Rawtani, D.; Khatri, N.; Tyagi, S.; Pandey, G. Nanotechnology-based recent approaches for sensing and remediation of pesticides. J. Environ. Manag. 2018, 206, 749-762. [CrossRef] [PubMed]

73. Topalov, A.; Molnár-Gábor, D.; Abramović, B.; Korom, S.; Peričin, D. Photocatalytic removal of the insecticide fenitrothion from water sensitized with $\mathrm{TiO}_{2}$. J. Photochem. Photobiol. Chem. 2003, 160, 195-201. [CrossRef]

74. Vela, N.; Calín, M.; Yáñez-Gascón, M.J.; Garrido, I.; Pérez-Lucas, G.; Fenoll, J.; Navarro, S. Photocatalytic oxidation of six pesticides listed as endocrine disruptor chemicals from wastewater using two different $\mathrm{TiO}_{2}$ samples at pilot plant scale under sunlight irradiation. J. Photochem. Photobiol. Chem. 2018, 353, 271-278. [CrossRef]

75. Ahmed, S.; Rasul, M.G.; Brown, R.; Hashib, M.A. Influence of parameters on the heterogeneous photocatalytic degradation of pesticides and phenolic contaminants in wastewater: A short review. J. Environ. Manag. 2011, 92, 311-330. [CrossRef]

76. Shifu, C.; Lei, J.; Wenming, T.; Xianliang, F. Fabrication, characterization and mechanism of a novel Z-scheme photocatalyst $\mathrm{NaNbO}_{3} / \mathrm{WO}_{3}$ with enhanced photocatalytic activity. Dalton Trans. 2013, 42, 10759. [CrossRef]

77. Ishibashi, K.; Fujishima, A.; Watanabe, T.; Hashimoto, K. Detection of active oxidative species in TiO2 photocatalysis using the fluorescence technique. Electrochem. Commun. 2000, 2, 207-210. [CrossRef]

78. Ibrahim, A.M.A.; Al-Ashqar, S.M.A. Spectroscopic and kinetic studies on the degradation of methylene blue using the supramolecular coordination polymer $\left[\left(\mathrm{Ph}_{3} \mathrm{Sn}\right) 4 \mathrm{Fe}(\mathrm{CN}) 6\right]$ as catalyst. Spectrochim. Acta. A Mol. Biomol. Spectrosc. 2012, 92, 238-244. [CrossRef]

79. Choi, K.-H.; Oh, S.-L.; Kim, D.-Y.; Jung, J.-S. Size Dependent Photocatalytic Activity of Photofunctional Magnetic Core-Shell $\left(\mathrm{Fe}_{3} \mathrm{O}_{4} @ \mathrm{TiO}_{2}\right)$ Particles. J. Nanosci. Nanotechnol. 2013, 13, 7134-7137. [CrossRef]

80. Zhou, Y.X.; Tong, L.; Chen, X.B.; Zeng, X.H. Fe3O4-ZnWO4 hybrid microspheres: Facile synthesis and magnetically recyclable photocatalytic performance. Micro-Nano Lett. 2013, 8, 32-34. [CrossRef]

81. Rajamohan, S.; Kumaravel, V.; Muthuramalingam, R.; Ayyadurai, S.; Abdel-Wahab, A.; Sub Kwak, B.; Kang, M.; Sreekantan, S. $\mathrm{Fe}_{3} \mathrm{O}_{4}-\mathrm{Ag}_{2} \mathrm{WO}_{4}$ : Facile synthesis, characterization and visible light assisted photocatalytic activity. New J. Chem. 2017, 41, 11722-11730. [CrossRef]

82. Liu, Z.; Chen, F.; Gao, Y.; Liu, Y.; Fang, P.; Wang, S. A novel synthetic route for magnetically retrievable $\mathrm{Bi}_{2} \mathrm{WO}_{6}$ hierarchical microspheres with enhanced visible photocatalytic performance. J. Mater. Chem. A 2013, 1, 7027. [CrossRef]

83. Zhou, Y.-X.; Tong, L.; Zeng, X.-H.; Chen, X.-B. $\mathrm{Fe}_{3} \mathrm{O}_{4} @ \mathrm{Bi}_{2} \mathrm{WO}_{6}$ Core-Shell Structured Microspheres: Facile Construction and Magnetically Recyclable Photocatalytic Activity Under Visible-Light. J. Nanosci. Nanotechnol. 2015, 15, 9868-9873. [CrossRef] [PubMed]

84. Karunakaran, C.; Vinayagamoorthy, P.; Jayabharathi, J. Nonquenching of Charge Carriers by $\mathrm{Fe}_{3} \mathrm{O}_{4} \mathrm{Core}_{\text {in }}$ $\mathrm{Fe}_{3} \mathrm{O}_{4} / \mathrm{ZnO}$ Nanosheet Photocatalyst. Langmuir 2014, 30, 15031-15039. [CrossRef]

85. Zhang, J.; Wang, W.-N.; Zhao, M.-L.; Zhang, C.-Y.; Huang, C.-X.; Cheng, S.; Xu, H.-M.; Qian, H.-S. Magnetically Recyclable $\mathrm{Fe}_{3} \mathrm{O}_{4} @ \mathrm{Zn}_{\mathrm{x}} \mathrm{Cd}_{1-\mathrm{x}} \mathrm{S}$ Core-Shell Microspheres for Visible Light-Mediated Photocatalysis. Langmuir 2018, 34, 9264-9271. [CrossRef] [PubMed]

(C) 2020 by the authors. Licensee MDPI, Basel, Switzerland. This article is an open access article distributed under the terms and conditions of the Creative Commons Attribution (CC BY) license (http://creativecommons.org/licenses/by/4.0/). 